\title{
Vertical distribution of chlorophyll in dynamically distinct regions of the southern Bay of Bengal
}

\author{
Venugopal Thushara ${ }^{1}$, Puthenveettil Narayana Menon Vinayachandran ${ }^{1}$, Adrian J. Matthews ${ }^{2}$, \\ Benjamin G. M. Webber ${ }^{3}$, and Bastien Y. Queste ${ }^{3}$ \\ ${ }^{1}$ Centre for Atmospheric and Oceanic Sciences, Indian Institute of Science, Bangalore, India \\ ${ }^{2}$ Centre for Ocean and Atmospheric Sciences, School of Environmental Sciences and School of Mathematics, \\ University of East Anglia, Norwich, UK \\ ${ }^{3}$ Centre for Ocean and Atmospheric Sciences, School of Environmental Sciences, University of East Anglia, Norwich, UK
}

Correspondence: Puthenveettil Narayana Menon Vinayachandran (vinay@iisc.ac.in)

Received: 22 June 2018 - Discussion started: 12 July 2018

Revised: 7 February 2019 - Accepted: 22 February 2019 - Published: 9 April 2019

\begin{abstract}
The Bay of Bengal (BoB) generally exhibits surface oligotrophy due to nutrient limitation induced by strong salinity stratification. Nevertheless, there are hotspots of high chlorophyll in the BoB where the monsoonal forcings are strong enough to break the stratification; one such region is the southern BoB, east of Sri Lanka. A recent field programme conducted during the summer monsoon of 2016, as a part of the Bay of Bengal Boundary Layer Experiment (BoBBLE), provides a unique high-resolution dataset of the vertical distribution of chlorophyll in the southern BoB using ocean gliders along with shipboard conductivitytemperature-depth (CTD) measurements. Observations were carried out for a duration of 12-20 days, covering the dynamically active regions of the Sri Lanka Dome (SLD) and the Southwest Monsoon Current (SMC). Mixing and upwelling induced by the monsoonal wind forcing enhanced surface chlorophyll concentrations $\left(0.3-0.7 \mathrm{mg} \mathrm{m}^{-3}\right)$. Prominent deep chlorophyll maxima (DCM; 0.3-1.2 $\mathrm{mg} \mathrm{m}^{-3}$ ) existed at intermediate depths $(20-50 \mathrm{~m})$, signifying the contribution of subsurface productivity to the biological carbon cycling in the BoB. The shape of chlorophyll profiles varied in different dynamical regimes; upwelling was associated with sharp and intense DCM, whereas mixing resulted in a diffuse and weaker DCM. Within the SLD, open-ocean Ekman suction favoured a substantial increase in chlorophyll. Farther east, where the thermocline was deeper, enhanced surface chlorophyll was associated with intermittent mixing events. Remote forcing by the westward propagating Rossby waves influenced the upper-ocean dynamics and
\end{abstract}

chlorophyll distribution in the southern BoB. Stabilizing surface freshening events and barrier-layer formation often inhibited the generation of surface chlorophyll. The pathway of the SMC intrusion was marked by a distinct band of chlorophyll, indicating the advective effect of biologically rich Arabian Sea waters. The region of the monsoon current exhibited the strongest DCM as well as the highest columnintegrated chlorophyll. Observations suggest that the persistence of DCM in the southern BoB is promoted by surface oligotrophy and shallow mixed layers. Results from a coupled physical-ecosystem model substantiate the dominant role of mixed layer processes associated with the monsoon in controlling the nutrient distribution and biological productivity in the southern BoB. The present study provides new insights into the vertical distribution of chlorophyll in the $\mathrm{BoB}$, emphasizing the need for extensive in situ sampling and ecosystem model-based efforts for a better understanding of the biophysical interactions and the potential climatic feedbacks.

\section{Introduction}

The Bay of Bengal (BoB) is fascinating, with its unique upper-ocean features strongly linked to the Indian Summer Monsoon (ISM) variability (Gadgil et al., 1984; Vecchi and Harrison, 2002; Shankar et al., 2007). The upper layer of the BoB, especially the northern BoB, is highly stable, owing to strong near-surface salinity stratification in the pres- 
ence of abundant freshwater influx from precipitation and rivers. The low salinity cap in the surface layers of the $\mathrm{BoB}$ leads to the formation of a shallow mixed layer and a barrier layer beneath (Vinayachandran et al., 2002; Wijesekera et al., 2016a), controlling air-sea interactions and the upperocean heat budget (Shenoi et al., 2002). In addition, monsoonal winds are relatively weak over the BoB, leading to a sluggish upper ocean, where vertical overturning and mixing processes are weak (Shetye et al., 1991; Madhupratap et al., 1996; Kumar et al., 2002; McCreary et al., 2009; Wiggert et al., 2009). This dynamical set-up imparts strong nutrient limitation on phytoplankton growth, leading to weak biological productivity in the BoB (Gomes et al., 2000; Kumar et al., 2002; Madhupratap et al., 2003). Compared to the highly productive Arabian Sea, chlorophyll distribution in the $\mathrm{BoB}$ is often light-limited, despite being located in the same tropical band, due to large cloud cover during the active phase of the monsoon (Kumar et al., 2010). In addition, the presence of suspended sediments in the vicinity of discharge from major rivers reduces the light availability for photosynthesis (Gomes et al., 2000; Kumar et al., 2004).

Though the basin-averaged productivity is weak in the $\mathrm{BoB}$, satellite and in situ observations reveal the presence of intense regional chlorophyll blooms (Vinayachandran and Mathew, 2003; Kumar et al., 2004, 2007). These blooms are clearly distinguishable in space and time, exhibiting elevated levels of chlorophyll $\left(>0.3 \mathrm{mg} \mathrm{m}^{-3}\right)$ with respect to the oligotrophic background state of the BoB. The evolution of chlorophyll blooms in the ocean is controlled by the ecosystem balance between the growth and loss rates as well as the physiological adaptations of the phytoplankton (Cullen, 2015; Behrenfeld and Boss, 2017). In the northern BoB where stratification is strong, surface chlorophyll levels are generally weak, except in association with coastal processes and eddy activity. The northwestern BoB is characterized by seasonal increase in chlorophyll in the presence of strong coastal upwelling induced by the alongshore winds during the summer monsoon (Shetye et al., 1991), which enriches the previously nutrient-limited euphotic zone (Thushara and Vinayachandran, 2016). In addition, nutrients supplied through the monsoonal river discharge support enhanced chlorophyll concentrations in the nearby coastal oceans (Kumar et al., 2004, 2007). The occurrence of mesoscale eddies is an additional forcing, favouring biological productivity through the vertical supply of nutrients (Kumar et al., 2007; Nuncio and Kumar, 2013). Productivity in the BoB is mostly confined to the coastal ocean and dynamical regions of the open ocean, such as the southern BoB, where the freshwater effects are relatively weaker (Vinayachandran and Mathew, 2003).

The southern $\mathrm{BoB}$, characterized by strong currents, intense mixing and upwelling, is one of the most dynamically active regions of the northern Indian Ocean (Murty et al., 1992; Schott et al., 1994; McCreary et al., 1996; Vinayachandran and Yamagata, 1998; Vinayachandran et al., 1999;
Shankar et al., 2002; Lee et al., 2016; Wijesekera et al., 2016b). Unlike the northern BoB, salinity stratification is relatively weak in the south, resulting in a deeper mixed layer. Prominent chlorophyll blooms are observed in the coastal and open-ocean regions of the southern BoB, closely linked to monsoon circulation (Vinayachandran, 2009). The region off the southern coast of Sri Lanka is characterized by high chlorophyll levels in summer, triggered by the coastal upwelling of nutrients (Vinayachandran et al., 2004). Cyclonic wind stress curl east of Sri Lanka during the summer monsoon leads to the formation of the Sri Lanka Dome (SLD; Vinayachandran and Yamagata, 1998), where open-ocean Ekman suction of nutrients triggers chlorophyll bloom generation (Vinayachandran et al., 2004). The Southwest Monsoon Current (SMC) intruding into the southern BoB (Vinayachandran and Yamagata, 1998; Vinayachandran et al., 2013; Jensen, 2001) carries biologically rich waters from the Indian and Sri Lankan coasts, supporting elevated levels of chlorophyll all along its path (Vinayachandran et al., 2004). After finding its way into the $\mathrm{BoB}$, the SMC bifurcates into several branches, and the associated cold-core eddies are observed as enhancing chlorophyll concentrations (Jyothibabu et al., 2015). During the winter monsoon, satellite observations and ecosystem models reveal the presence of moderate blooms triggered by open-ocean upwelling in the southwestern BoB (Vinayachandran and Mathew, 2003; Vinayachandran et al., 2005). In addition to the seasonal forcings, frequent occurrence of tropical cyclones favour short-lived isolated patches of intense blooms (Madhu et al., 2002; Vinayachandran and Mathew, 2003; Rao et al., 2006).

The biophysical interactions in the BoB have not been well explored, and our present understanding of the mechanisms determining the spatial and temporal distribution of productivity in the $\mathrm{BoB}$ is limited, owing to the scarcity of observational data and model simulations. Ocean colour retrievals by satellites are widely affected by the presence of cloud cover during monsoon, the period when the surface chlorophyll levels are the highest in the BoB. Past observational studies (Vinayachandran and Mathew, 2003; Vinayachandran et al., 2004; Kumar et al., 2004, 2007; Jyothibabu et al., 2015) have contributed to our understanding of the biological productivity in the BoB, suggesting that the dynamics controlling the chlorophyll distribution are complex, determined by the competing effects of winds (local as well as remote) and freshwater flux on the mixed layer processes. However, the spatial and temporal coverage of observations is insufficient in obtaining a complete picture of the chlorophyll distribution. We also lack estimates of subsurface chlorophyll, and hence, its contribution to the column-integrated productivity (Kumar et al., 2009) has received little attention.

Until now, the paucity of previous chlorophyll measurements precluded a detailed investigation of the biophysical feedbacks and the possible controls on the surface properties and air-sea heat and gas exchanges of the BoB. The present study is aimed at documenting the observed chloro- 
phyll distribution of the southern bay, obtained from four ocean gliders and conductivity-temperature-depth (CTD) measurements taken during the Bay of Bengal Boundary Layer Experiment (BoBBLE; Vinayachandran et al., 2018) field programme. Enhanced levels of surface chlorophyll were observed at all glider locations, in response to the monsoonal forcings at seasonal and synoptic timescales. The BoBBLE data reveal the presence of prominent deep chlorophyll maxima in the $\mathrm{BoB}$, which are rarely captured by satellites. Results from a coupled physical-ecosystem model are incorporated to evaluate the model performance in reproducing the summer blooms in the $\mathrm{BoB}$ and to analyse the associated biophysical interactions in detail. Section 2 describes the observational data and the ecosystem model; Sect. 3 examines the vertical distribution of chlorophyll in the southern bay, co-limited by light and nutrients, in response to the monsoonal wind and freshwater forcings. A summary and conclusions are given in the last section.

\section{Observations and modelling}

Observations were carried out in the region to the eastern coast of Sri Lanka, on board ORV Sindhu Sadhana, which sailed from Chennai on 24 June and returned on 23 July 2016 (Fig. 1). The present analyses are based on the data along $8^{\circ} \mathrm{N}$, extending from $85.3^{\circ} \mathrm{E}$ (hereafter referred to as TSW) to $89^{\circ} \mathrm{E}$ (hereafter referred to as TSE), including a 10-day CTD time series station at TSE. Shipboard measurements were taken back and forth along this longitudinal transect; the ship sailed from TSW to TSE from 29 June to 3 July, stayed at TSE from 3 to 15 July and returned back to TSW on 20 July. The longitudinal transect runs across the productive regions of the SLD and SMC, covering a distance of about $400 \mathrm{~km}$.

\subsection{In situ measurements of chlorophyll}

The vertical distribution of chlorophyll fluorescence was measured along the cruise track using ocean gliders and a shipboard CTD. Ocean gliders are buoyancy-driven autonomous underwater vehicles designed to dive from the surface to the deep ocean and back following a sawtooth pattern, collecting vertical profiles of oceanographic properties (Eriksen et al., 2001). Four gliders (SG579, SG534, SG532 and SG620) with biophysical sensors were deployed along the transect at $8^{\circ} \mathrm{N}$ (Fig. 1). They were positioned at specified locations; hence the measurements made can be considered to be time series data (but note that SG579 shifted almost $60 \mathrm{~km}$ westwards during the observational period but stayed within the SLD). The gliders provided high-resolution measurements of biophysical properties, both in space (at least $0.5 \mathrm{~m}$ in vertical) and time (4-7 profiles a day). Data collection starts within the top $1 \mathrm{~m}$ of the upper ocean, enabling better sampling of surface properties compared with conven-

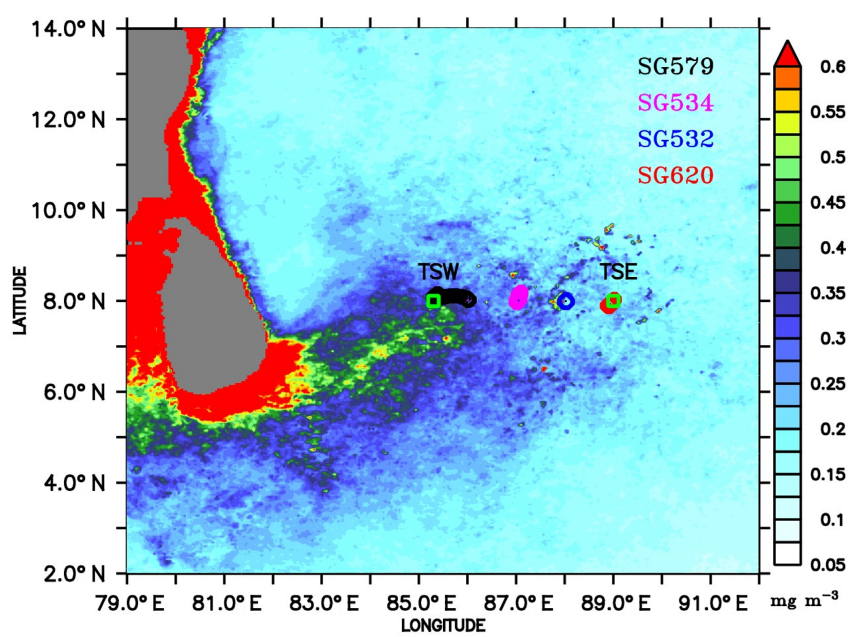

Figure 1. Chlorophyll $\left(\mathrm{mg} \mathrm{m}^{-3}\right)$ climatology (2007-2016) for the month of July, obtained from Ocean Colour Climate Change Initiative (OC-CCI) Version 3.1. Ocean glider locations are marked as circles along $8^{\circ} \mathrm{N}$, where the shipboard observations were performed. The glider deployment locations are $8^{\circ} \mathrm{N}, 86^{\circ} \mathrm{E} ; 8^{\circ} \mathrm{N}$, $87^{\circ} \mathrm{E} ; 8^{\circ} \mathrm{N}, 88^{\circ} \mathrm{E}$; and $8^{\circ} \mathrm{N}, 88^{\circ} 54^{\prime} \mathrm{E}$, for SG579, SG534, SG532, and SG620 respectively. Observational periods of gliders are 30 June-20 July, 1-17 July, 2-16 July, and 3-14 July 2016 for SG579, SG534, SG532, and SG620 respectively. TSW and TSE (squares) are sampling locations at $8^{\circ} \mathrm{N}, 85.3^{\circ} \mathrm{E}$, and $8^{\circ} \mathrm{N}, 89^{\circ} \mathrm{E}$, respectively.

tional measurement techniques. Each glider was equipped with a Sea-Bird Electronics CTD package, a global positioning system (GPS) and WET Labs Triplet ECO Puck sensors. All ECO Pucks had at least one fluorescence channel, measuring chlorophyll, and were accompanied by one to two backscatter channels. In total, 405 dives were performed by the four gliders, including shallow $(\sim 700 \mathrm{~m})$ and deep $(\sim 1000 \mathrm{~m})$ profiles, where each dive lasted $3-5 \mathrm{~h}$. The typical speed of the gliders was about $0.25 \mathrm{~m} \mathrm{~s}^{-1}$, and vertical velocities ranged between 0.10 and $0.15 \mathrm{~m} \mathrm{~s}^{-1}$. The shipboard CTD was equipped with auxiliary sensors for fluorescence, which are factory calibrated. In addition to the gliders, the CTD collected a total number of 147 profiles along the cruise track. The CTD data used for the present analysis are smoothed in time and depth spaces by $3 \mathrm{~h}$ and $3 \mathrm{~m}$ respectively.

After quality control, the data from each glider were optimally interpolated (Bretherton et al., 1976) onto a twodimensional (depth-time) equally spaced grid, following Matthews et al. (2014). First, a background-gridded field was constructed from a weighted average of the observations. A two-dimensional Gaussian weighting function, with e-folding scales of $2 \mathrm{~m}$ for depth and $3 \mathrm{~h}$ for time, was used to map each observation onto the depth-time grid. An optimal interpolation increment was then calculated, again using the Gaussian weighting function, to calculate the final gridded field. The longitudinal positions of the gliders were then 
used to create a single glider dataset. The two-dimensional (depth-time) optimally interpolated fields from each of the four gliders were combined into a single three-dimensional (longitude-depth-time) gridded dataset by linearly interpolating over longitude.

Observed fluorescence from gliders was corrected for non-photochemical quenching during daylight hours using chlorophyll-to-backscatter ratios during night-time (Thomalla et al., 2018). The glider chlorophyll values exhibited an offset similar to that found by Webber et al. (2014), with higher concentrations compared to the concurrent observations from the shipboard CTD. However, the glider data are reliable for explaining the processes underlying the bloom evolution, since the spatial and temporal variability of chlorophyll were consistent with the CTD observations. For the present analysis, the glider data corrected for nonphotochemical quenching were scaled to represent the in situ chlorophyll value using the CTD data. An independent scale factor was calculated for each glider's ECOPuck using linear regression with the available nearby CTD profiles, where the distance between the ship and glider is not more than a quarter of a degree, and the time difference is not more than an hour.

\subsection{Coupled physical-ecosystem model}

A coupled physical-ecosystem model was employed to study the observed chlorophyll distribution in the southern BoB during the BoBBLE field programme. The physical model is based on the Geophysical Fluid Dynamics Laboratory (GFDL) Modular Ocean Model Version 4 (MOM4p1; Griffies et al., 2004), configured for the Indian Ocean region extending from 30 to $120^{\circ} \mathrm{E}$ and $30^{\circ} \mathrm{N}$ to $30^{\circ} \mathrm{S}$ (Kurian and Vinayachandran, 2007; Behara and Vinayachandran, 2016). The horizontal resolution of the model is $0.25^{\circ}$, and the vertical grid spacing is $5 \mathrm{~m}$ in the upper $60 \mathrm{~m}$, increasing to $10 \mathrm{~m}$ at $100 \mathrm{~m}$ depth, $20 \mathrm{~m}$ at $200 \mathrm{~m}$ depth and $700 \mathrm{~m}$ at $5000 \mathrm{~m}$ depth, altogether forming 40 levels. The ETOPO5 dataset with 5 min resolution is used to set up the model topography, with the minimum depth of the ocean fixed at $30 \mathrm{~m}$. A no-flux condition is applied across the model boundaries. Additionally, a no-slip condition is applied to the closed western and northern boundaries. The open southern and eastern boundaries consist of sponge layers where temperature and salinity fields are relaxed to climatology (Conkright et al., 1998), with a timescale of 30 days. The model mixing schemes are based on Large et al. (1994) and Chassignet and Garraffo (2001). Turbulent fluxes and upwelling longwave radiation are calculated using the bulk formula (Large and Yeager, 2004), and the penetrative shortwave radiation is parameterized based on Morel and Antoine (1994).

The ecosystem model used in this study is the Tracers of Phytoplankton with Allometric Zooplankton (TOPAZ) model (Dunne et al., 2010), consisting of 25 tracers, including micro- and macronutrients, carbon, oxygen, and lithogenic materials. The biogeochemical cycles are calculated with flexible nutrient stoichiometry. The phytoplankton class consists of three groups: small, large and diazotrophs. The small group represents the nanoplankton, which are weakly limited by nutrients and strongly limited by grazing. The large group represents the microplankton, which are strongly limited by nutrients and weakly limited by grazing, with the ability to store iron internally. Diazotrophs (nitrogen fixers) form a relatively small fraction of the total biomass (Gnanadesikan et al., 2011). The model also includes dissolved organic matter and heterotrophic biomass. The biogeochemical mechanisms consist of nitrogen fixation, denitrification, gas exchange, atmospheric decomposition, scavenging and sediment processes. Co-limitation by light and nutrients controls the phytoplankton physiology and growth (Geider et al., 1997) with a temperature dependency (Eppley, 1972). Grazing is parameterized using a size-based relationship (Dunne et al., 2005) in which the large phytoplankton group dominates the ecosystem at high growth rates and biomass, whereas the small phytoplankton group dominates at low growth rates and biomass. Detritus production is temperature dependent and calculated as a fraction of phytoplankton (Dunne et al., 2005). Nitrification is inhibited by light (Ward et al., 1982). A detailed technical description of the ecosystem model is available in Dunne et al. (2010), and important model parameters are given in Table 1.

The model configuration used in the present analysis is similar to that in Thushara and Vinayachandran (2016). The physical model was spun up for a period of 10 years, starting from a state of rest using climatological initial fields for temperature and salinity (Conkright et al., 1998). This was followed by a coupled spin-up for another 10 years, after switching on the ecosystem model. A stable annual cycle was obtained for both physical and biological fields after the spin-up, and this was followed by an interannual run from 1 April 2015 to 31 December 2016. Nutrients for initializing the ecosystem model were obtained from the World Ocean Atlas (WOA09), and no-flux conditions were applied at the open boundaries. The model forcing fields include air temperature, specific humidity, surface pressure, downward shortwave and longwave radiation fluxes, at hourly frequency from Goddard Earth Observing System (GEOS) Modern-Era Retrospective analysis for Research and Applications, Version 2 (MERRA-2 ; Rienecker et al., 2011). Wind speed and wind stress forcings were obtained from the Advanced SCATterometer (ASCAT; Figa-Saldaña et al., 2002). The model freshwater forcings include daily precipitation from the Tropical Rainfall Measuring Mission (TRMM; Huffman et al., 2007) and monthly climatological river runoff from the Center for Sustainability and the Global Environment (SAGE; Vörösmarty et al., 1996). Weekly chlorophyll from the Sea-viewing Wide Field-of-View Sensor (SeaWiFS; Sweeney et al., 2005) was used for the calculation of penetrative shortwave radiation. 
Table 1. Details of biological parameters used in the ecosystem model.

\begin{tabular}{|c|c|c|}
\hline Parameter & Description & Value \\
\hline$K_{\mathrm{NH}_{4}}^{\mathrm{Lg}}$ & Half-saturation coefficient for ammonium uptake by large phytoplankton & $6 \times 10^{-7} \mathrm{~mol} \mathrm{NH}_{4} \mathrm{~kg}^{-1}$ \\
\hline$K_{\mathrm{NH}_{4}}^{\mathrm{Sm}_{4}}$ & Half-saturation coefficient for ammonium uptake by small phytoplankton & $2 \times 10^{-7} \mathrm{~mol} \mathrm{NH}_{4} \mathrm{~kg}^{-1}$ \\
\hline$K_{\mathrm{NO}_{3}}^{\mathrm{Lg}}$ & Half-saturation coefficient for nitrate uptake by large phytoplankton & $6 \times 10^{-6} \mathrm{~mol} \mathrm{NO}_{3} \mathrm{~kg}^{-1}$ \\
\hline$K_{\mathrm{NO}_{3}}^{\mathrm{Sm}_{3}^{3}}$ & Half-saturation coefficient for nitrate uptake by small phytoplankton & $2 \times 10^{-6} \mathrm{~mol} \mathrm{NO}_{3} \mathrm{~kg}^{-1}$ \\
\hline$K_{\mathrm{PO}_{4}}^{\mathrm{Lg}}$ & Half-saturation coefficient for phosphate uptake by large phytoplankton & $6 \times 10^{-7} \mathrm{~mol} \mathrm{PO}_{4} \mathrm{~kg}^{-1}$ \\
\hline$K_{\mathrm{PO}_{4}}^{\mathrm{Sm}_{4}}$ & Half-saturation coefficient for phosphate uptake by small phytoplankton & $2 \times 10^{-7} \mathrm{~mol} \mathrm{PO}_{4} \mathrm{~kg}^{-1}$ \\
\hline$K_{\mathrm{PO}_{4}}^{\mathrm{Di}^{4}}$ & Half-saturation coefficient for phosphate uptake by diazotrophs & $6 \times 10^{-7} \mathrm{~mol} \mathrm{PO}_{4} \mathrm{~kg}^{-1}$ \\
\hline$K_{\mathrm{SiO}_{4}}^{\mathrm{Lg}}$ & Half-saturation coefficient for silicate uptake by large phytoplankton & $1 \times 10^{-6} \mathrm{~mol} \mathrm{SiO}_{4} \mathrm{~kg}^{-1}$ \\
\hline$K_{\mathrm{Fe}}^{\mathrm{Lg}}$ & Half-saturation coefficient for iron uptake by large phytoplankton & $3 \times 10^{-9} \mathrm{~mol} \mathrm{Fe} \mathrm{kg}^{-1}$ \\
\hline$K_{\mathrm{Fe}}^{\mathrm{Sm}}$ & Half-saturation coefficient for iron uptake by small phytoplankton & $1 \times 10^{-9} \mathrm{~mol} \mathrm{Fe} \mathrm{kg}^{-1}$ \\
\hline$K_{\mathrm{Fe}}^{\mathrm{Di}}$ & Half-saturation coefficient for iron uptake by diazotrophs & $3 \times 10^{-9} \mathrm{~mol} \mathrm{Fe} \mathrm{kg}^{-1}$ \\
\hline$P_{\text {Çmax }}^{\mathrm{Lg}}$ & Maximum carbon assimilation rate for large phytoplankton & $1.5 \times 10^{-5} \mathrm{~s}^{-1}$ \\
\hline$P_{\mathrm{Cmax}}^{\mathrm{Sm}}$ & Maximum carbon assimilation rate for small phytoplankton & $1.5 \times 10^{-5} \mathrm{~s}^{-1}$ \\
\hline$P_{\mathrm{Cmax}}^{\mathrm{Din}}$ & Maximum carbon assimilation rate for diazotrophs & $0.6 \times 10^{-5} \mathrm{~s}^{-1}$ \\
\hline$\theta_{\max }^{\mathrm{Lg}}$ & Maximum chlorophyll-to-carbon ratio for large phytoplankton & $0.06 \mathrm{~g} \mathrm{Chl} \mathrm{g} \mathrm{C}^{-1}$ \\
\hline$\theta_{\max }^{\mathrm{Sm}}$ & Maximum chlorophyll-to-carbon ratio for small phytoplankton & $0.04 \mathrm{~g} \mathrm{Chl} \mathrm{g} \mathrm{C}^{-1}$ \\
\hline$\theta_{\max }^{\mathrm{Di}}$ & Maximum chlorophyll-to-carbon ratio for diazotrophs & $0.04 \mathrm{~g} \mathrm{Chl} \mathrm{g} \mathrm{C}^{-1}$ \\
\hline$\zeta$ & Cost of biosynthesis & 0.1 \\
\hline$\kappa$ & Eppley’s temperature coefficient & $0.063^{\circ} \mathrm{C}^{-1}$ \\
\hline$\lambda_{0}$ & Phytoplankton grazing rate constant at $0^{\circ} \mathrm{C}$ & 0.19 day $^{-1}$ \\
\hline
\end{tabular}

\section{Results and discussion}

The BoBBLE field programme coincided with a suppressed phase of the Boreal Summer Intraseasonal Oscillation (BSISO), when the convective activity was weak over the southern BoB (see Fig. 4 of Vinayachandran et al., 2018). Precipitation was minimal during most of the observational period, until the establishment of the succeeding active phase of the BSISO by the end of the programme. Surplus insolation associated with reduced atmospheric convection suggests that light availability only played a minor role in limiting the surface chlorophyll distribution. In the presence of heavy cloud cover associated with the monsoon, light availability is generally believed to limit the growth of phytoplankton in the Bay of Bengal. However, observational evidence also shows that light is not an important limiting factor in the low latitudes (Laws, 2013; Behrenfeld and Boss, 2017), where the phytoplankton growth is mainly determined by nutrient availability (Moore et al., 2013). According to a recent study in the northern $\mathrm{BoB}$ by Jyothibabu et al. (2018), high PAR conditions were associated with low surface chlorophyll, and during low PAR conditions chlorophyll levels increased considerably.

Monsoonal cloud cover, especially during the active phase of BSISO, limits the continuous sampling of ocean colour from satellites, restricting the analysis of daily or weekly evolution of the chlorophyll blooms. Ocean colour data obtained from European Space Agency (ESA) Ocean
Colour Climate Change Initiative Version 3.1 (OC-CCI v3.1) merged product reveal that the southern bay exhibited high chlorophyll levels during the BoBBLE period. The mean chlorophyll concentration in the southern bay $\left(82-92^{\circ} \mathrm{E}\right.$ and $4-12^{\circ} \mathrm{N}$ ) averaged for the month of July was about $0.2 \mathrm{mg} \mathrm{m}^{-3}$, which is comparable to that of the previous years.

\subsection{Hydrography}

To provide a dynamical context for the chlorophyll distribution, the hydrography of the southern BoB during the BoBBLE period is briefly described here. Further details can be found in Vinayachandran et al. (2018) and Webber et al. (2018). In response to the prevailing atmospheric conditions, the upper ocean in the southern bay exhibited large spatial variability at seasonal and synoptic timescales. The climatological distribution of surface temperature shows cooler waters in the region of the SMC, creating an east-west contrast along $8^{\circ} \mathrm{N}$ (see Fig. 1 of Vinayachandran et al., 2018). Weaker winds and higher insolation, associated with the suppressed phase of BSISO during the observational period, resulted in high sea surface temperature (SST). The mean SST obtained from the Group for High Resolution Sea Surface Temperature (GHRSST; Chao et al., 2009) dataset, averaged for the observational period (27 June-21 July 2016), was $\sim 29.3^{\circ} \mathrm{C}$ at TSW and $\sim 0.5^{\circ} \mathrm{C}$ less at TSE, deviating from the climatology. The mean sea surface salinity (SSS) from 


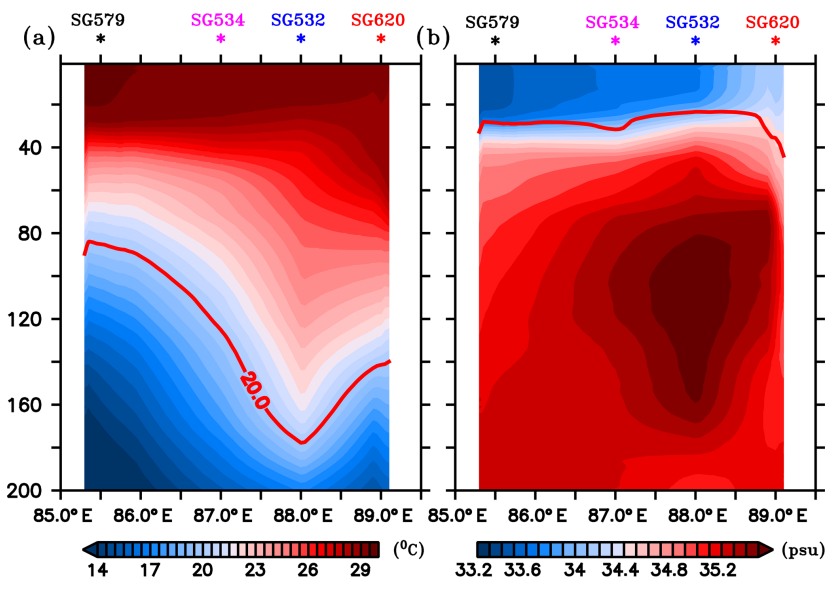

Figure 2. Depth-longitude sections of (a) temperature $\left({ }^{\circ} \mathrm{C}\right)$ and (b) salinity (psu) obtained from ocean gliders averaged for 314 July, the common period when all the gliders performed data sampling. Mean glider locations are marked at the top of each panel. Red curves in (a) and (b) represent the thermocline and MLD respectively. The thermocline is represented by the $20^{\circ} \mathrm{C}$ isotherm (D20). MLD is calculated as the depth where density is equal to the sea surface density plus an increase in density equivalent to a reduction in temperature of $0.8^{\circ} \mathrm{C}$.

the Soil Moisture Active Passive (SMAP; Fore et al., 2016) mission was $\sim 33.3 \mathrm{psu}$ at TSW, and farther east at TSE, salinity was 0.8 psu higher.

A depth-longitude section of temperature and salinity recorded by gliders, averaged for the period 3-14 July, is shown in Fig. 2. Gliders in the west (SG579 and SG532) exhibited higher SST and lower SSS compared to those in the east (SG534 and SG620), consistent with the satellite observations. The thermocline, represented by the $20^{\circ} \mathrm{C}$ isotherm (D20), exhibited an east-west dip along $8^{\circ} \mathrm{N}$ extending from TSW to $88^{\circ} \mathrm{E}$, followed by a rise towards TSE (Fig. 2a). The western sector of the transect (TSW) lies within the SLD, where open-ocean Ekman suction leads to the doming of the thermocline. At TSW, D20 was located at a depth of about $80 \mathrm{~m}$, as observed by SG579, and deepened towards the east. In the region of the high salinity core of the SMC intrusion (Fig. 2b), D20 was much deeper, located at a depth of about $180 \mathrm{~m}$ (SG532). At the eastern end of the transect (TSE), D20 slightly shoaled by about $40 \mathrm{~m}$, as observed by SG620.

Circulation in the southern bay during the observational period is characterized by a strong cyclonic gyre in the region of the SLD and the monsoon current which flows northeastward (Webber et al., 2018). During the beginning of the observational period, the SMC was strong, with surface velocities ranging between 0.5 and $0.8 \mathrm{~m} \mathrm{~s}^{-1}$ (Fig. 3a-g). The region of the SLD was characterized by strong negative sea level anomalies (SLAs) of about $-20 \mathrm{~cm}$. By the end of the first week of July, the SMC weakened and shifted westward, reducing the zonal extent of the SLD (Fig. 3h-1). Farther east, towards the eastern edge of the monsoon current, the up-
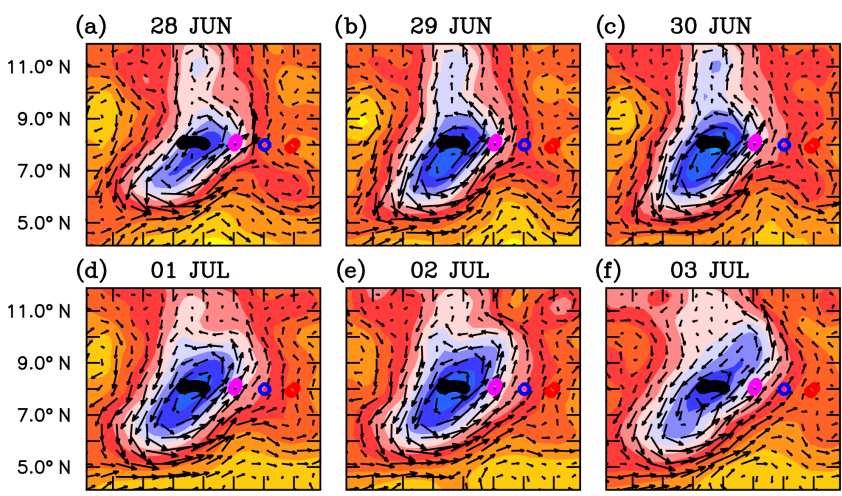

(e) 02 JUL

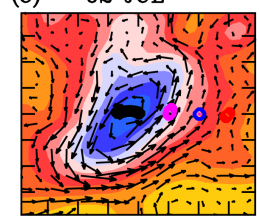

(f) 03 JUL

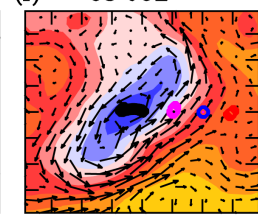

(g) 04 JUL

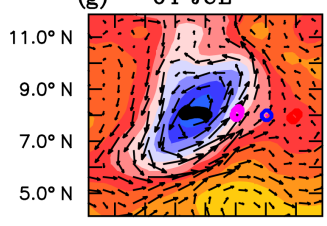

(h) 05 JUL
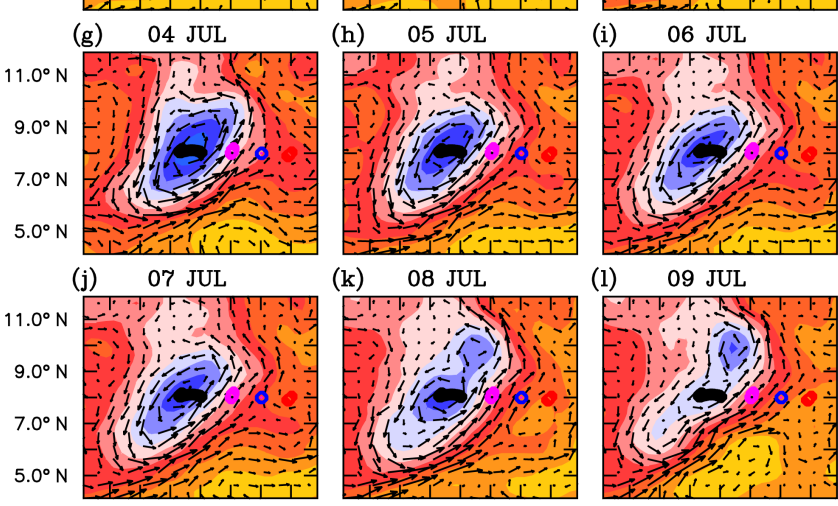

(k) 08 JUL
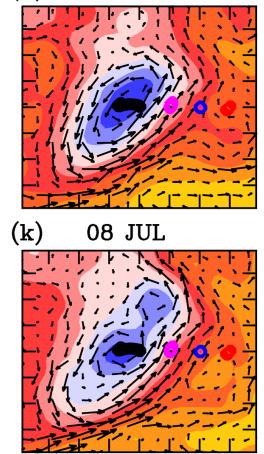

(1) 09 JUL
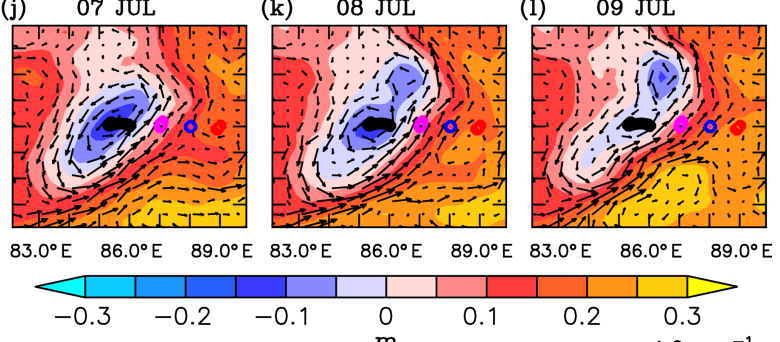

Figure 3. Sea level anomalies (SLAs; $m$ ) and surface currents $\left(\mathrm{m} \mathrm{s}^{-1}\right)$ from AVISO for the period 28 June to 9 July 2016. The glider locations are marked along $8^{\circ} \mathrm{N}$ (circles). Evolution of Sri Lanka Dome (SLD) is represented by the negative SLAs embedded within the cyclonic circulation.

per ocean was relatively less dynamic, with weaker currents $\left(0.1-0.3 \mathrm{~m} \mathrm{~s}^{-1}\right)$ and positive sea level anomalies $(10-20 \mathrm{~cm})$.

The spatial variability in the upper-ocean dynamics of the $\mathrm{BoB}$, determined by local and remote forcings associated with the monsoon, influence the chlorophyll distribution as well, which is of interest in the present study. The following sections characterize the observed chlorophyll in the southern bay in terms of intensities and the vertical distribution during the BoBBLE period. The associated mechanisms determining the chlorophyll distribution are analysed, combining hydrographical observations and results from an ecosystem model.

\subsection{Observed chlorophyll distribution}

\subsubsection{Surface bloom events}

The gliders cover an east-west transect across the regions of the SLD and SMC (Fig. 1), providing time series measurements of chlorophyll. Surface layers remained weakly productive during most of the observational period, however, 

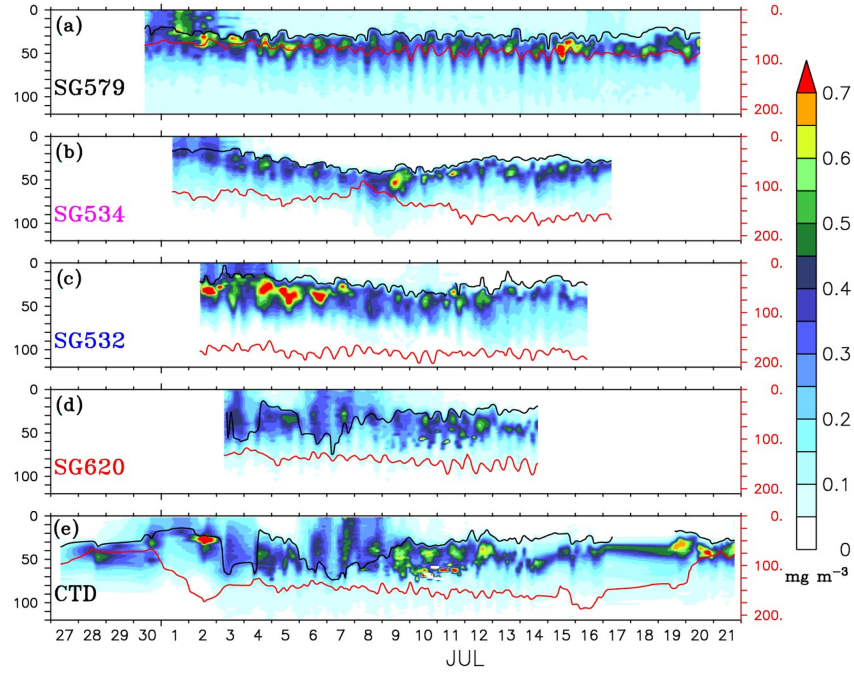

Figure 4. Time-depth sections of chlorophyll $\left(\mathrm{mg} \mathrm{m}^{-3}\right)$ from ocean gliders (a-d) and CTD (e). The glider measurements are considered to be time series data for the locations shown in Fig. 1. CTD observations were collected at TSW $\left(85.3^{\circ} \mathrm{E}, 8^{\circ} \mathrm{N}\right)$ from 27 to 29 June, after which the ship sailed towards TSE $\left(89^{\circ} \mathrm{E}, 8^{\circ} \mathrm{N}\right)$. From $3-$ 15 July, time series measurements were made at TSE, after which the ship sailed back towards the west and reached TSW on 20 July. The black curve represents the mixed layer depth, which is calculated as the depth where density is equal to the sea surface density plus an increase in density equivalent to a reduction in temperature of $0.8^{\circ} \mathrm{C}$. The thermocline (red curve) is represented by the $20^{\circ} \mathrm{C}$ isotherm (D20). Note that the $y$ axis at the right side has a different scale.

events of enhanced chlorophyll were observed at all of the four glider locations (Fig. 4a-d) as well as in the CTD data (Fig. 4e). Surface chlorophyll concentrations from gliders and the CTD are shown in Fig. 5. During the beginning of the observational period, concurrent occurrence of elevated chlorophyll levels was observed within the SLD and along the path of the SMC, as recorded by SG579, SG534 and SG532. At SG620 (TSE), two events were recorded with relatively weaker magnitudes of chlorophyll compared to the other glider locations. CTD measurements captured the surface chlorophyll events in the region of the SMC on 1-2 July and at TSE on 6-8 July, consistent with the glider observations. The ship and glider were about $10 \mathrm{~km}$ apart during most of the observational period at TSE, and hence an exact agreement in chlorophyll time series is not expected.

Within the SLD. Summer chlorophyll blooms in the region of the SLD have been reported earlier using satellite images of ocean colour (Vinayachandran et al., 2004). The daily evolution of SLAs and currents from archiving, validation, and interpretation of satellite oceanographic data (AVISO) show the intensification of the SLD during the early part (29 June-3 July) of the BoBBLE field programme (Fig. 3). Observations from SG579, which falls right inside the dome, revealed the development of a surface chlorophyll

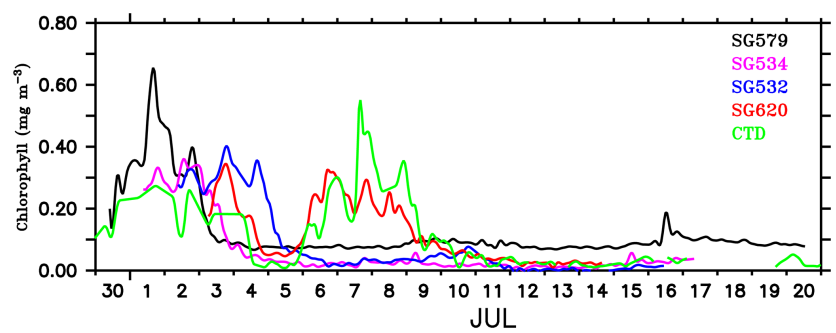

Figure 5. Surface chlorophyll concentration $\left(\mathrm{mg} \mathrm{m}^{-3}\right)$ from ocean gliders (at $1 \mathrm{~m}$ ) and the shipboard CTD (at $3 \mathrm{~m}$ ). SG579 (black) falls within the region of SLD, SG534 (magenta) and SG532 (blue) along the path of SMC and SG620 (red) at the outer edge of SMC, as shown in Fig. 1. CTD (green) observations were collected along the $8^{\circ} \mathrm{N}$ section, as described in Fig. 4 .

bloom during the same period (Fig. 4a; 30 June-2 July). Chlorophyll concentration at the surface was $\sim 0.3 \mathrm{mg} \mathrm{m}^{-3}$ on 30 June, increased to $\sim 0.7 \mathrm{mg} \mathrm{m}^{-3}$ on 1 July and reduced to $\sim 0.4 \mathrm{mg} \mathrm{m}^{-3}$ on 2 July (Fig. 5). CTD observations were available within the dome on 28-29 June, before the ship started moving eastwards from TSW. Until 29 June, surface chlorophyll values were much lower $\left(<0.1 \mathrm{mg} \mathrm{m}^{-3}\right)$, with higher concentrations mostly confined to a depth of about $30-60 \mathrm{~m}$ (Fig. 4e). Hence, it can be inferred that the surface chlorophyll bloom within the dome probably commenced on 30 June, peaked on 1 July and started decaying on 2 July. There were no glider observations of chlorophyll before 30 June to corroborate the CTD data.

The observed increase in surface chlorophyll at SG579 coincided with the intensification of the SLD, characterized by negative SLAs embedded within the cyclonic circulation to the east of Sri Lanka (Fig. 3). Time series of minimum SLAs in the region of the dome show that the SLD attained its peak by the end of June (Fig. 6a). Sea level anomalies decreased to about $-0.3 \mathrm{~m}$ on 30 June. The thermocline was shallow, located at a depth of about $70 \mathrm{~m}$, during the peak phase of the surface chlorophyll bloom (1 July; Fig. 4). The doming of the thermocline indicates dynamical uplifting of the nutricline and enhanced nutrient concentrations in the euphotic zone (Wilson and Coles, 2005; Turk et al., 2001). The chlorophyll bloom event was characterized by lower surface temperatures $\left(28.6^{\circ} \mathrm{C}\right)$ and higher surface salinities $(33.95 \mathrm{psu})$ with upsloping isotherms and isohalines (not shown), compared to the period when the surface chlorophyll concentrations were weak. The decay of surface chlorophyll bloom after 2 July (Fig. 5) followed the weakening of the dome (Fig. 6a). Surface temperature increased by $0.7^{\circ} \mathrm{C}$, and surface salinity decreased by $\sim 1.5 \mathrm{psu}$ on 3 July. The weakening of the dome indicates reduced upwelling of the subsurface nutrients. Nutrient limitation restrains the growth of phytoplankton, leading to the decay of surface blooms, when the biological loss terms dominate. CTD observations within the dome until 29 June, when the ship was at TSW, show that the subsurface chlorophyll concentrations were weak $\left(<0.5 \mathrm{mg} \mathrm{m}^{-3}\right)$ 

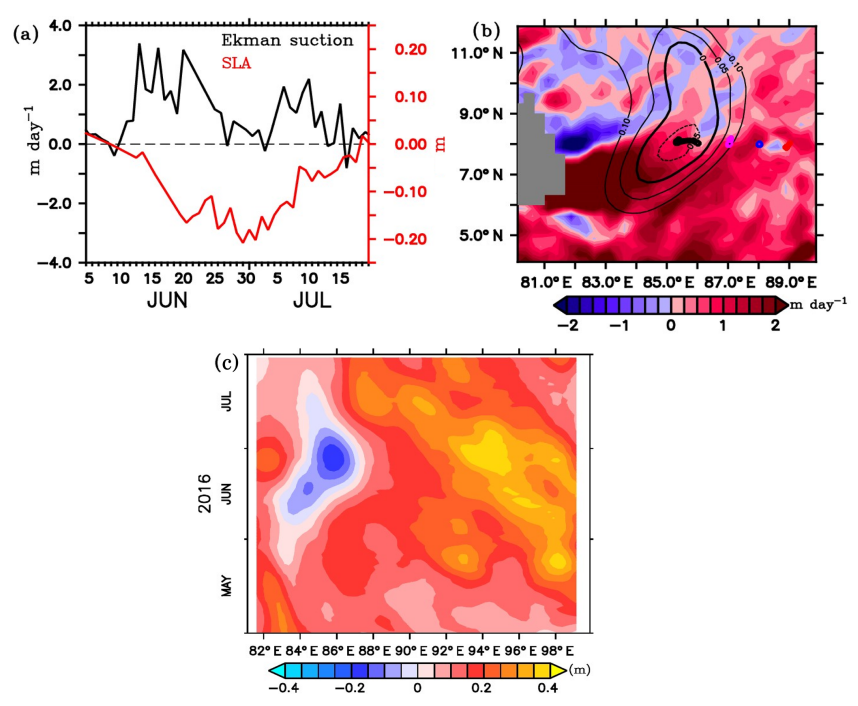

Figure 6. (a) Time series of Ekman vertical velocity $\left(\mathrm{mday}^{-1}\right.$; black) around the location of SG579 $\left(85-86^{\circ} \mathrm{E}, 7.5-8.5^{\circ} \mathrm{N}\right)$, and the minimum SLAs (m; red) in the region of the Sri Lanka Dome (SLD) from 5 June to 20 July. (b) Ekman vertical velocity averaged for the BoBBLE observational period (24 June-23 July) in the southern BoB. Contours of SLAs are overlayed. (c) Time-longitude Hovmöller diagram of SLAs along $8^{\circ} \mathrm{N}$ between 81 and $100^{\circ} \mathrm{E}$ from May to July.

just before the surface chlorophyll event (Fig. 4e). This indicates that the surface chlorophyll bloom is probably not a result of the vertical redistribution of subsurface phytoplankton. On the other hand, the vertical transport of subsurface nutrients to the near-surface layers can favour the growth of phytoplankton in the given timescales (Laws, 2013), leading to the intensification of surface chlorophyll. Though the evolution of observed chlorophyll follows the dynamics of the study region, the concurrent role of biological loss terms, including grazing, mortality and sinking rates, cannot be ignored, which requires additional data sampling.

The southern BoB was characterized by cyclonic wind stress curl, inducing Ekman suction during the field programme. The vertical transport of nutrients to the surface sunlit layers through Ekman suction favours the generation of phytoplankton blooms (Vinayachandran et al., 2004; Wijesekera et al., 2016a). Spatial distribution of Ekman vertical velocities, calculated using ASCAT winds and averaged for the BoBBLE observational period (24 June-23 July), indicates widespread upwelling in the southern BoB (Fig. 6b). Time series of Ekman vertical velocities in the location of SG579 show that Ekman suction peaked to about 2$3 \mathrm{~m} \mathrm{day}^{-1}$ by mid-June (Fig. 6a). Ekman vertical velocities remained to be favourable for upwelling $\left(0.4-0.7 \mathrm{~m} \mathrm{day}^{-1}\right)$ during the period of surface bloom (30 June-2 July), though the magnitudes were relatively weaker. Strong upwelling in the second half of June, prior to the surface chlorophyll event, is presumed to provide a favourable preconditioning by lifting the nitracline towards the surface.

During the decaying phase of the SLD in July, Ekman vertical velocities were positive, with peak values of about $2 \mathrm{~m} \mathrm{day}^{-1}$ (Fig. 6a). This indicates the dominant influence of remote effects propagating from the eastern boundary of the BoB (Vinayachandran and Yamagata, 1998; Shankar et al., 2002; Wijesekera et al., 2016a; Burns et al., 2017; Webber et al., 2018). A time-longitude Hovmöller diagram of SLAs from AVISO during May-July along $8^{\circ} \mathrm{N}$, between 80 and $100^{\circ} \mathrm{E}$, is shown in Fig. 6c. The decay period of the SLD coincides with the arrival of positive SLAs from east, representing the westward propagation of downwelling Rossby waves (Webber et al., 2018). Rossby waves propagating from the eastern boundary of the BoB can influence the depth of thermocline (nitracline) in the study region. This shows that, despite the Ekman suction, remote forcings contributed to the weakening of the SLD and hence the chlorophyll distribution. As far as surface chlorophyll is concerned, the proximity of nutricline to the surface is of primary concern. Results from the ecosystem model have been used to identify the dominant forcings controlling the vertical displacement of nitracline (see Sect. 3.3.1).

Along the path of the SMC. Increased surface chlorophyll levels were observed at SG534 and SG532 on 1-2 July (Fig. 4b) and 2-4 July (Fig. 4c) respectively. Both gliders were located along the path of the SMC, with SG532 in the region of the subsurface high salinity core (Fig. 2b). Surface chlorophyll concentration peaked to about 0.35 and $0.4 \mathrm{mg} \mathrm{m}^{-3}$ at SG534 and SG532 respectively (Fig. 5). This increase in chlorophyll was associated with lower temperatures (28.7 and $29.1{ }^{\circ} \mathrm{C}$ for SG532 and SG534 respectively) and higher salinities (34.4 and 34 psu for SG532 and SG534 respectively) at the surface, compared to the period when the chlorophyll levels were weak.

Along the path of the SMC, when the surface chlorophyll levels were high, the thermocline was deep $(\sim 100-130 \mathrm{~m}$ at SG534 and $\sim 160-180 \mathrm{~m}$ at SG532), which is $40-100 \mathrm{~m}$ deeper than that in the region of the dome (Fig. $4 a-c)$. The spatial variability of thermocline is evident from the CTD observations as well, showing a shallow thermocline during the beginning (27-30 June) and end (20-21 July) of the field programme, when the ship was in the west, and a deeper thermocline farther east (2-18 July; Fig. 4e). A deeper thermocline generally indicates a deeper nitracline and stronger nutrient limitation in the surface layers. At the same time, the region of the SMC is also subject to an additional supply of biologically rich waters advected from the coasts of India and Sri Lanka (Vinayachandran et al., 2004). In addition, the possibility of lateral advection of nutrients and chlorophyll generated within the SLD to the nearby glider locations cannot be ignored (see Sect. 3.3.2).

Mixing events. Chlorophyll distribution observed outside the dome, farther east at TSE, differed from that in the region of the SLD and SMC, in terms of intensity as well as the 


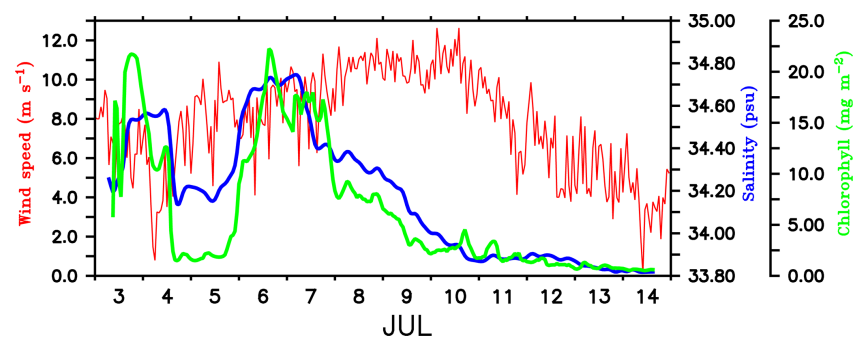

Figure 7. Time series of wind speed $\left(\mathrm{m} \mathrm{s}^{-1}\right.$; red) from shipboard AWS at TSE $\left(89^{\circ} \mathrm{E}, 8^{\circ} \mathrm{N}\right)$. Surface salinity (psu; blue) and total chlorophyll integrated over the mixed layer $\left(\mathrm{mg} \mathrm{m}^{-2}\right.$; green) is from SG620, deployed at TSE. MLD is calculated as the depth where density is equal to the sea surface density plus an increase in density equivalent to a reduction in temperature of $0.8^{\circ} \mathrm{C}$.

vertical structure. SG620 captured two events of enhanced surface chlorophyll: the first on 3 July and the second on 6-8 July (Fig. 4d). The surface chlorophyll concentrations were $\sim 0.3 \mathrm{mg} \mathrm{m}^{-3}$ during both the events (Fig. 5), characterized by low surface temperatures and high surface salinities. The observed SST from SG620 was about $28.7^{\circ} \mathrm{C}$ on 3 July and $28.8^{\circ} \mathrm{C}$ on 6 July. Surface salinities were about 34.5 psu and 34.7 psu on 3 July and 6 July respectively. Temporal coverage of the first event is insufficient in explaining its evolution, since the chlorophyll bloom decayed immediately after 3 July, when the sampling began. Wind speed measured by the shipboard automatic weather station (AWS) was $5-9 \mathrm{~m} \mathrm{~s}^{-1}$ on 3 July (Fig. 7). A deeper mixed layer depth (MLD) of about $60 \mathrm{~m}$ during this period indicates that vertical mixing is presumably the primary factor which favoured the increase in surface chlorophyll. The second event was captured by the CTD measurements as well (Fig. 4e), consistent with the glider data. This event coincided with a phase of increasing wind speed of about 6-11 $\mathrm{m} \mathrm{s}^{-1}$ (6-7 July; Fig. 7). Subsequent deepening of the mixed layer ( $\sim 70 \mathrm{~m}$; Fig. $4 \mathrm{~d}$ ) suggests the role of mixing and entrainment in triggering the intensification of surface chlorophyll. Enhanced vertical processes favour intensification of surface chlorophyll by transporting nutrients to the euphotic zone and by redistributing the subsurface chlorophyll to the surface layers.

The decay period of the observed surface chlorophyll blooms (Fig. 5) coincided with the development of intermittent freshening events at the surface: the first on 4-5 July and the second on 7-10 July. The initial drop in surface salinity during the freshening events was $\sim 0.4$ psu on 4 and 7 July (Fig. 7). The surface chlorophyll decreased by about 0.3 and $0.27 \mathrm{mg} \mathrm{m}^{-3}$ during the first and second freshening events respectively (Fig. 5). There was an overall reduction in total chlorophyll integrated over the mixed layer by about $20 \mathrm{mg} \mathrm{m}^{-2}$ during both the freshening events (Fig. 7).

The freshening events were characterized by the formation of barrier layers (Vinayachandran et al., 2018). Vertical profiles of temperature, salinity and chlorophyll from
SG620 during different stages of the surface bloom evolution are shown in Fig. 8a-e. During the peak of the surface chlorophyll blooms ( 3 and 6 July), the mixed layer was deep $(\sim 50-55 \mathrm{~m})$, with an almost uniform distribution of biophysical properties (Fig. 8a and c), and the isothermal layer was close to the mixed layer. The days following the peak in surface chlorophyll (4-5 and 8-10 July) were characterized by strong salinity stratification with the arrival of freshwater in the surface layers. Surface salinity decreased by about 0.25 and 0.75 psu for the first and second events respectively (Fig. $8 \mathrm{~b}$ and e). The mixed layer shoaled to $\sim 30 \mathrm{~m}$, whereas the isothermal layer remained around the same depth (Fig. 8b, d and e). The associated development of barrier layers is noticeable, with a thickness of $\sim 25-$ $30 \mathrm{~m}$. Following the salinity stratification and barrier-layer formation, surface chlorophyll decreased by about 0.1 and $0.15 \mathrm{mg} \mathrm{m}^{-3}$ during the first and second events respectively. Vertical profiles obtained from the CTD at TSE for the same period are given in Fig. 8f-j. With the arrival of freshwater, surface salinity from the CTD decreased by about 0.25 and 0.5 psu during the first and second events respectively, and the corresponding decrease in surface chlorophyll was 0.1 and $0.15 \mathrm{mg} \mathrm{m}^{-3}$ respectively. The mixed layers shoaled by about $25-30 \mathrm{~m}$, creating strong barrier layers (Fig. $8 \mathrm{~g}$, i and j). Even though high wind speed $\left(\sim 10-12 \mathrm{~m} \mathrm{~s}^{-1}\right)$ conditions prevailed during the decay period of the bloom, freshwater induced stratification was strong enough to overcome the wind effect (Fig. 7). The observed biological response to freshwater is similar to that in the northern bay, where stratification inhibits the development of phytoplankton blooms in the surface layers by restricting the vertical transport of subsurface nutrients and chlorophyll (Kumar et al., 2002).

\subsubsection{Deep chlorophyll maxima}

The formation of DCM is determined by a variety of mechanisms, including an enhanced growth rate of phytoplankton co-limited by light and nutrients at optimum depths, photoacclimation of pigment content, and physiologically controlled swimming behaviours and buoyancy regulation (Cullen, 2015). The BoB is reported to have prominent DCM (Murty et al., 2000; Madhu et al., 2006), which contribute to the column-integrated productivity (Gomes et al., 2000; Madhupratap et al., 2003; Li et al., 2012), with magnitudes often comparable to the highly productive Arabian Sea (Kumar et al., 2009). However, little is known about the distribution of subsurface chlorophyll in the BoB and the associated processes, due to the lack of observations.

During the BoBBLE field programme, both the glider and CTD observations revealed the presence of prominent DCM in the southern bay (Figs. 4 and 9a). The chlorophyll maxima were centred at a depth of about $20-50 \mathrm{~m}$, mostly below the mixed layer and above the thermocline (Anderson, 1969). Similar depth ranges of DCM were reported previously by Gomes et al. (2000) and Kumar et al. (2009) in the 


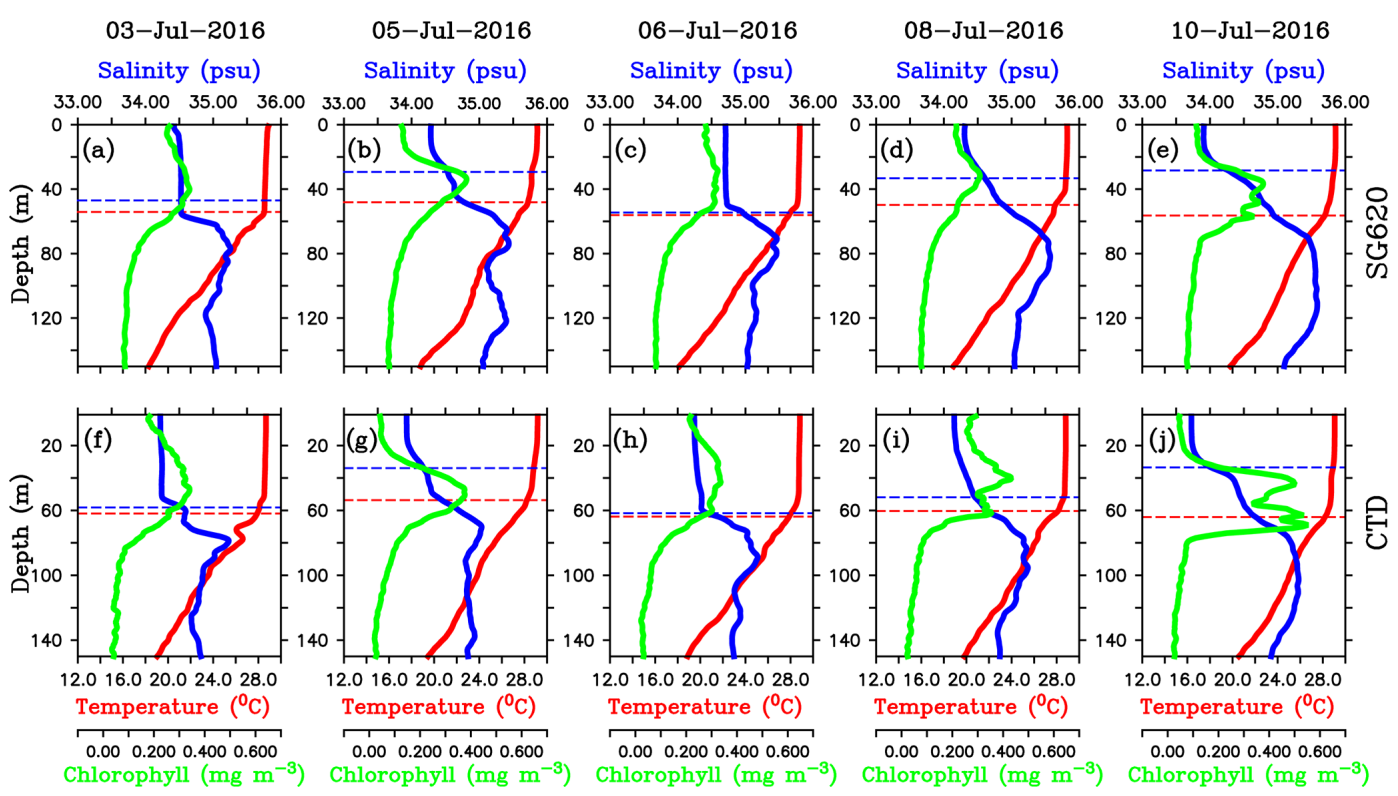

Figure 8. Daily mean vertical profiles of temperature $\left({ }^{\circ} \mathrm{C}\right.$; red), salinity (psu; blue) and chlorophyll ( $\mathrm{mg} \mathrm{m}^{-3}$; green) for selected days from (a-e) SG620 and (f-j) CTD. The blue dashed line indicates the mixed layer depth, which is calculated as the depth where density is equal to the sea surface density plus an increase in density equivalent to a reduction in temperature of $0.8^{\circ} \mathrm{C}$. The red dashed line indicates isothermal layer depth (ILD) which is calculated as the depth where the temperature is cooler than SST by $0.8^{\circ} \mathrm{C}$. The region between the MLD and ILD represents the barrier layer.

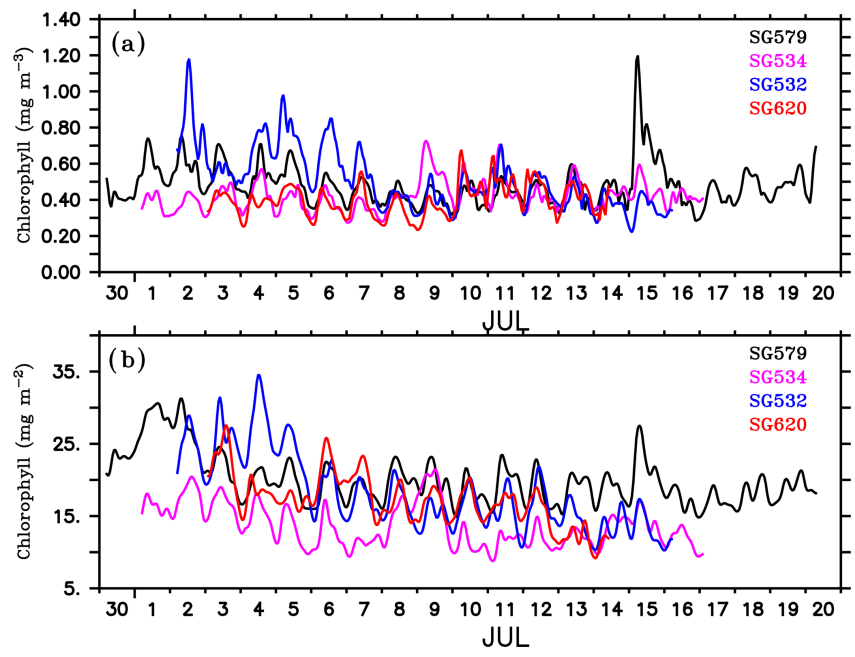

Figure 9. (a) Concentration of deep chlorophyll maxima $\left(\mathrm{mg} \mathrm{m}^{-3}\right)$ and (b) depth-integrated $(100 \mathrm{~m})$ chlorophyll $\left(\mathrm{mg} \mathrm{m}^{-2}\right)$ from ocean gliders: SG579 (black), SG534 (magenta), SG532 (blue) and SG620 (red).

BoB. Subsurface chlorophyll concentrations ranged from 0.3 to $1.2 \mathrm{mg} \mathrm{m}^{-3}$ (Fig. 9a), which were $2-3$ times higher than the surface values (Fig. 5). DCM were prominent in the region of the SLD and along the path of the SMC (Fig. 4ac), whereas outside the dome, the subsurface concentrations were weaker (Fig. 4d).
Vertical profiles of chlorophyll from the gliders during events of enhanced surface chlorophyll are shown in Fig. 10. The mean DCM were intense, located at a depth of about 20$30 \mathrm{~m}$, in the region of the SLD and the SMC (Fig. 10a-c). The DCM became weaker, diffused and slightly deeper (30$40 \mathrm{~m}$ ) at TSE (Fig. 10d and e). Intensification of DCM in the region of SLD can be related to the doming of thermocline. The vertical transport of nutrients is affected by the changes in thermocline depth, and hence, the variability of nutricline is found to be largely correlated with the variability of thermocline in the tropical oceans (Turk et al., 2001; Wilson and Adamec, 2002; Wilson and Coles, 2005). The shoaling of thermocline in the region of the SLD indicates an upward sloping of nutricline, indicating nutrient enrichment in the euphotic zone and enhanced accumulation of phytoplankton. At TSE (SG620), where the thermocline was deeper, mixing often penetrated to deeper layers, pushing the mixed layer towards the DCM (Fig. 4d and e). This favours the dilution of DCM and a decrease in phytoplankton concentration at the subsurface through mixing with the weakly productive surface layers, leaving a near-homogeneous distribution of chlorophyll within the water column (Fig. 10d and e).

Subsurface chlorophyll concentrations were noticeably higher in the region of the SMC (Figs. 4c and 10c). Maximum intensities were recorded by SG532, with magnitudes ranging from 0.7 to $1.2 \mathrm{mg} \mathrm{m}^{-3}$ on 2-7 July (Fig. 9a). Column-integrated chlorophyll was also observed to be the highest at SG532 (4 July), with total chlorophyll in the top $100 \mathrm{~m}$ reaching as high as $35 \mathrm{mg} \mathrm{m}^{-2}$ (Fig. 9b), which is 

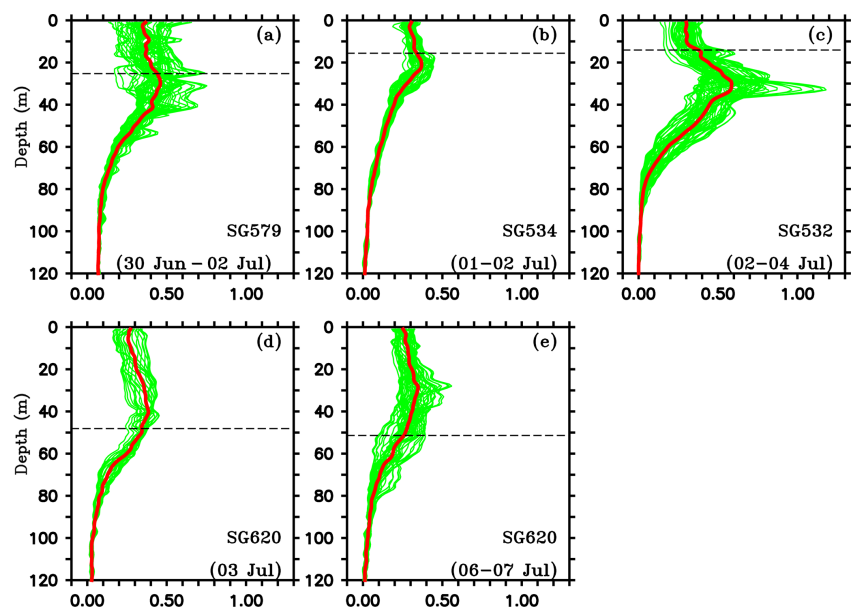

Figure 10. Vertical profiles of chlorophyll $\left(\mathrm{mg} \mathrm{m}^{-3}\right)$ from ocean gliders during surface bloom events, as shown in Fig. 5. Individual profiles are given in green, and the corresponding mean profiles are given in red. Black dashed line represents the mixed layer depth, which is calculated as the depth where density is equal to the sea surface density plus an increase in density equivalent to a reduction in temperature of $0.8^{\circ} \mathrm{C}$.

comparable to the previously observed values in the $\mathrm{BoB}$ (Gomes et al., 2000; Madhupratap et al., 2003; Kumar et al., 2009; Li et al., 2012). The region of the SMC is characterized by the advection of upwelled chlorophyll-rich water from the western coast of India and the southern coast of Sri Lanka. An isolated maximum $\left(1.2 \mathrm{mg} \mathrm{m}^{-3}\right)$ in the DCM was recorded by SG579 in the region of SLD in the latter half of the observational period (15 July). However, in the absence of surface blooms, the corresponding columnintegrated chlorophyll was lower $\left(28 \mathrm{mg} \mathrm{m}^{-2}\right)$ compared to the region of the SMC.

The core subsurface intrusion of the SMC, below the low salinity surface waters of the southern bay, was located around SG532 during the observational period (Vinayachandran et al., 2018; Webber et al., 2018). The vertical salinity structure reveals a high salinity core at $88^{\circ} \mathrm{E}$, extending up to a depth of about $180 \mathrm{~m}$, with salinity values as high as 35.8 psu (Fig. 2b). Arabian Sea water, which is rich in nutrients and chlorophyll sliding through the subsurface layers of the $\mathrm{BoB}$, is presumed to contribute to the intensification of the DCM at SG532, suggesting a key role of SMC intrusion in the biological budget of the southern bay. However, it may be noted that the location of the subsurface high salinity core was much deeper relative to the depth of DCM. Most of the high salinity intrusions at $88^{\circ} \mathrm{E}$ occurred below $80 \mathrm{~m}$, in the deeper layers of the euphotic zone. Dynamics behind the distribution of the DCM in the region of the high salinity core are intricate. Though the effect of lateral advection by the SMC on DCM cannot be ignored, the possible contribution of vertical processes in supplying the subsurface nutrients or chlorophyll needs to be examined in detail.
Subsurface chlorophyll concentrations were observed to intensify for shorter durations following the weakening of surface blooms (Fig. 4). Increases in DCM concentrations after the decay of surface blooms were about $0.13,0.37$ and $0.25 \mathrm{mg} \mathrm{m}^{-3}$ at SG534, SG532 and SG620 respectively (Fig. 9a). In the region of the SLD (SG579), the subsurface chlorophyll concentrations increased to $\sim 0.7 \mathrm{mg} \mathrm{m}^{-3}$ during the peak phase of the surface bloom ( 1 July). During the decaying phase of the surface bloom (2-5 July), these high chlorophyll levels $\left(0.7 \mathrm{mg} \mathrm{m}^{-3}\right)$ were maintained at the subsurface and weakened afterwards (Fig. 9a). This indicates enhanced biological productivity at the subsurface, after the triggering mechanisms inducing the surface blooms have weakened. During the decaying phase of surface blooms, the upper layers of the water column became less turbulent or more stably stratified (Fig. 8), inhibiting the vertical transport of nutrients and chlorophyll. For example, the surface bloom event at SG620 weakened in response to the freshening event on 8 July (Fig. 8b). Consequently, there was an increase in DCM, which lasted for a period of about 2-3 days, from 10 to 12 July (Fig. 9a). The observed intensification of DCM in the absence of surface chlorophyll can be explained in terms of changes in subsurface irradiance levels. During the decaying phase of the surface bloom, the self-shading effect of surface phytoplankton weakens, enhancing the light availability at the subsurface, which is examined in the following section.

\subsubsection{Role of light limitation}

Chlorophyll interactive penetrative radiation was calculated at TSE for the period 4-14 July, following the Morel and Antoine (1994) and Manizza et al. (2005) scheme as given below:

$$
\begin{aligned}
I_{(z)} & =I_{\mathrm{IR}} \cdot e^{-k_{\mathrm{IR}} z}+I_{\mathrm{RED}(z-1)} \cdot e^{-k_{(\mathrm{RED})} \Delta z}+I_{\mathrm{BLUE}(z-1)} \\
& \cdot e^{-k_{(\mathrm{BLUE})} \Delta z}
\end{aligned}
$$

where $I_{(z)}$ is the penetrative radiation at each depth level, $I_{\mathrm{IR}}=I_{0} \cdot(0.58)$ represents the infrared band, $I_{\mathrm{VIS}}=I_{0}$. (0.42) represents the visible band and $k_{\mathrm{IR}}=2.86 \mathrm{~m}^{-1}$ is the light attenuation coefficient for the infrared band. The selfshading effect of phytoplankton is taken into account so that at every vertical level $(z)$, the available visible light is computed as a function of irradiance at the level just above $(z-1)$. $\Delta z$ is the thickness of each layer between two vertical levels, which is $1 \mathrm{~m}$ in the present glider data. Visible light is split into two averaged wavelength bands as given below,

$I_{\mathrm{RED}}=I_{\mathrm{BLUE}}=\frac{I_{\mathrm{VIS}}}{2}$,

where $I_{\text {RED }}$ and $I_{\text {BLUE }}$ are the irradiances in red and bluegreen bands respectively. 
The light attenuation coefficients for the two visible bands is calculated as a function of chlorophyll concentration ([Chl]) as follows:

$k_{(\mathrm{RED})}=0.225+0.037 \cdot[\mathrm{Chl}]^{0.629}$,

$k_{(\mathrm{BLUE})}=0.0232+0.074 \cdot[\mathrm{Chl}]^{0.674}$.

Surface irradiance $\left(I_{0}\right)$ for the above calculations was obtained from shipboard AWS (Fig. 11a) and chlorophyll from SG620 (Fig. 4d). In order to exclude the effect of daily variation in surface irradiance, a diurnal composite of radiation (Fig. 11a) for the period 4-14 July is also used for the calculations. Photosynthetically active radiation (PAR) at each vertical level $(z)$ was estimated using the following expression:

$\operatorname{PAR}_{(z)}=I_{\operatorname{vis}_{(z)}} \times \frac{2.5 \times 10^{18}}{6.023 \times 10^{23}}$,

where $I_{\operatorname{vis}(z)}$ is the penetrative radiation $\left(\mathrm{W} \mathrm{m}^{-2}\right)$ in the visible range calculated using the light model and $2.5 \times$ $10^{18}$ quanta s $^{-1} \mathrm{~W}^{-1}$ is the conversion factor obtained from Morel and Smith (1974). The depth of euphotic zone $\left(Z_{\mathrm{eu}}\right)$ was calculated as the depth at which light reduces to $1 \%$ of the surface PAR value. Considering the fact that phytoplankton sees the absolute light level and not the percentage (Banse, 2004), the depth of threshold isolume $\left(Z_{0.415}\right)$ is taken as the depth where PAR is $0.415 \mathrm{E} \mathrm{m}^{-2}$ day $^{-1}$ below which light is insufficient to support photosynthesis (Letelier et al., 2004; Boss and Behrenfeld, 2010). An einstein (E) is a mole of photons, i.e., $6.023 \times 10^{23}$ photons.

Estimated penetrative radiation $\left(\mathrm{W} \mathrm{m}^{-2}\right)$ using the observed surface irradiance and the diurnal composite are shown in Fig. 11b and c respectively. The corresponding depths of euphotic zone and the threshold isolume obtained from the calculated PAR values are overlayed. Nearly $40 \%-$ $60 \%$ of the radiation was absorbed in the top $1 \mathrm{~m}$ of the water column and $80 \%-90 \%$ in the top $30 \mathrm{~m}$. Below the DCM, irradiance levels were substantially weaker $\left(<10 \mathrm{~W} \mathrm{~m}^{-2}\right)$. During the daylight hours of peak insolation, $Z_{0.415}$ extended to $70-110 \mathrm{~m}$, with a well-defined diurnal cycle. During days of enhanced surface chlorophyll, $Z_{0.415}$ and $Z_{\text {eu }}$ were shallow. $Z_{0.415}$ shoaled to a depth of about $70-80 \mathrm{~m}$, and $Z_{\text {eu }}$ was about $\sim 50 \mathrm{~m}$ during the chlorophyll bloom event at the surface on 6-7 July. The shoaling of the $Z_{0.415}$ and $Z_{\text {eu }}$ indicates the self-shading effect of surface phytoplankton. Elevated levels of chlorophyll enhance the absorption of radiation in the surface layers (Fig. 11b). Calculations using the diurnal composite of irradiance also give similar results (Fig. 11c). Enhanced attenuation of radiation by near-surface phytoplankton reduces the irradiance levels in the deeper layers and strengthens the light limitation on phytoplankton growth in the subsurface. As a result, bloom activity weakens in the subsurface layers, despite the availability of nutrients.
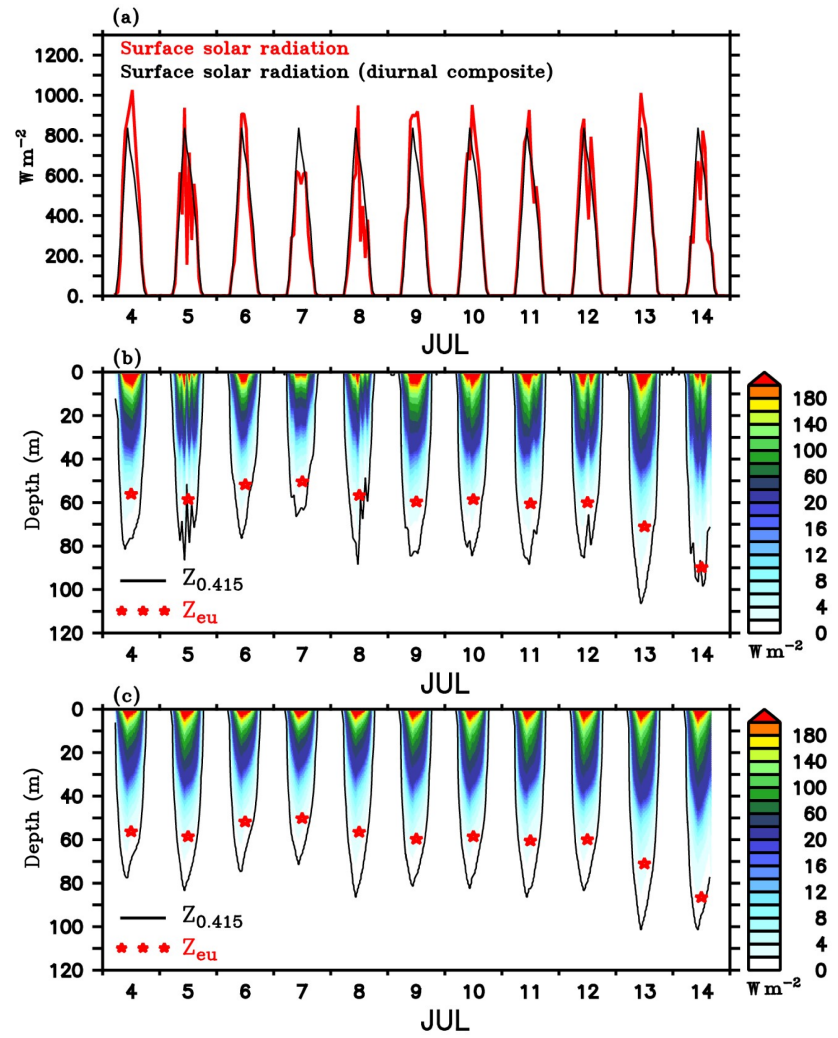

Figure 11. (a) Surface solar radiation measured by the shipboard AWS at TSE from 4 to 14 July (red), and the corresponding diurnal composite (black) calculated for the same period. Penetrative shortwave radiation is $\left(\mathrm{W} \mathrm{m}^{-2}\right)$ calculated following Morel and Antoine (1994) and Manizza et al. (2005) scheme using (b) observed and (c) diurnal composite of radiation. Chlorophyll from SG620 is used for the calculations. Photosynthetically active radiation (PAR; $\mathrm{E} \mathrm{m}^{-2} \mathrm{~s}^{-1}$ ) was estimated from the calculated penetrative radiation in the visible range, following Morel and Smith (1974). The red stars in (b) and (c) represent daily averaged depth of euphotic zone $\left(Z_{\mathrm{eu}}, \mathrm{m}\right)$ which is taken as the depth at which light reduces to $1 \%$ of the surface PAR value. The black contours in (b) and (c) represent the depth of threshold isolume $\left(Z_{0.415}, \mathrm{~m}\right)$ taken as the depth at which PAR is $0.415 \mathrm{E} \mathrm{m}^{-2} \mathrm{~s}^{-1}$.

Following the decay of surface blooms owing to nutrient limitation, $Z_{0.415}$ and $Z_{\text {eu }}$ increased due to the penetration of radiation to deeper layers (Perry et al., 2008). $Z_{0.415}$ and $Z_{\text {eu }}$ deepened by about 25 and $10 \mathrm{~m}$ respectively on 8 July (Fig. 11b). Enhanced light availability in the subsurface layers favours the intensification of DCM (Figs. 4d, e and Fig. 8). It should be noted that the DCM may not represent a deep biomass maximum, as photoacclimation (Cullen, 1982; Geider, 1987; Mateus et al., 2012) leads to changes in carbon-to-chlorophyll ratios. At the base of the euphotic layer, the cellular concentration of chlorophyll will increase as an adaptation to the lower irradiance levels (Cullen, 2015). 


\subsection{Model simulation}

A coupled physical-ecosystem model, employed to study the aforementioned biophysical interactions in the BoBBLE region, enabled further understanding of the three-dimensional mixed layer processes controlling the evolution of chlorophyll blooms. The role of horizontal advection by the SMC and dynamics of the SLD in determining the simulated distribution of nutrients and chlorophyll are analysed in detail. The model provides a fairly good representation of the biophysical features in the BoB. The physical model reproduces the observed seasonal and intraseasonal features of the Indian Ocean, with a realistic representation of the mixed layer processes and the heat and freshwater budgets (Kurian and Vinayachandran, 2006; Kurian and Vinayachandran, 2007; Vinayachandran and Kurian, 2007; Behara and Vinayachandran, 2016). Basin-averaged SST in the $\mathrm{BoB}\left(80-100^{\circ} \mathrm{E}\right.$ and $0-25^{\circ} \mathrm{N}$ ) for the month of July is about $28.37^{\circ} \mathrm{C}$, with a cold bias of $0.85^{\circ} \mathrm{C}$ compared to the GHRSST observations. The seasonal temperature distribution of the southern bay, including the cooling associated with upwelling off the coasts of India and Sri Lanka and the development of the cold pool, is well represented. The model reproduces the low salinity plumes associated with freshwater influx in the northern bay and high salinity intrusions from the Arabian Sea into the southern bay. Mean surface salinity for the basin is about 32.59 psu for the month of July, which exceeds SMAP observations by about $0.6 \mathrm{psu}$. The intrusion of the SMC into the $\mathrm{BoB}$ and its bifurcation into several branches is reproduced by the model. The vertical distribution of salinity reveals intermittent occurrence of high salinity cores at deeper levels, associated with the subsurface intrusion of the SMC. The model reproduces a well-developed SLD, characterized by negative SLAs $(-10 \mathrm{~cm})$ embedded within the cyclonic circulation east of Sri Lanka, consistent with the AVISO observations.

The TOPAZ ecosystem model simulates the mean distribution of oceanic productivity well (Sarmiento et al., 2010; Pastor et al., 2013; Sedigh Marvasti et al., 2016), and the biophysical interactions associated with major climatic events including the Indian Ocean Dipole, El Niño-Southern Oscillation and Atlantic Multidecadal Oscillation (Park and Kug, 2014; Park et al., 2014; Gnanadesikan et al., 2014). The model provides a realistic representation of the monsoonal biophysical interactions in the Indian Ocean and has been used to explain the bloom dynamics of the northwestern $\mathrm{BoB}$ during the summer monsoon (Thushara and Vinayachandran, 2016) and the northeastern Arabian Sea during winter (Vijith et al., 2016).

For the present analysis, simulated surface chlorophyll is validated using monthly means obtained from the OC-CCI merged product. The observed spatial distribution of surface chlorophyll, averaged for the month of July to be consistent with the BoBBLE period, is shown in Fig. 12a. Along the path of the SMC, a distinct band of chlorophyll is present, with concentrations of about $0.3-0.6 \mathrm{mg} \mathrm{m}^{-3}$. The band extends from the southern coast of Sri Lanka up to about $11^{\circ} \mathrm{N}$ and $89^{\circ} \mathrm{E}$, indicating lateral transport of nutrients and chlorophyll carried by the SMC from the upwelling regions off the coasts of India and Sri Lanka. Seasonal evolution of chlorophyll in the region of the SLD is not well captured by the satellites, probably because of gaps in the ocean colour retrieval during the peak phase of the dome (29 June to 2 July). Moderate chlorophyll concentrations $\left(0.2-0.3 \mathrm{mg} \mathrm{m}^{-3}\right)$ are observed in regions farther east and southeast of the monsoon current.

\subsubsection{Simulated chlorophyll distribution}

The observed spatial distribution of surface chlorophyll in the $\mathrm{BoB}$ is well represented by the model (Fig. 12b), with prominent chlorophyll blooms in the coastal ocean, northwestern bay and the southern bay (Vinayachandran, 2009). Chlorophyll concentrations are the highest along the coastal regions, with magnitudes exceeding $1 \mathrm{mg} \mathrm{m}^{-3}$. The northwestern bay is characterized by the seasonal occurrence of upwelling blooms triggered by coastal Ekman suction and advection towards the offshore regions (Thushara and Vinayachandran, 2016). The southern bay exhibits isolated patches of chlorophyll in the region of the SLD and along the path of the SMC. Surface chlorophyll concentrations are about $0.6-0.7$ and $0.3-0.4 \mathrm{mg} \mathrm{m}^{-3}$ in the region of the SLD and the SMC respectively. The model chlorophyll is generally weaker compared to satellite observations. The bias can be attributed either to the deficiencies in external nutrient inputs in the model or to the overestimation of coastal blooms by satellites in the presence of optically active constituents other than chlorophyll (Gregg and Casey, 2004; BlondeauPatissier et al., 2014). The presence of DCM is well represented by the model, consistent with the glider and CTD observations. Realistic representation of the chlorophyll distribution indicates that the model is suitable for explaining the underlying mechanisms. It may also be noted that the model parameterizations on different biological controls can lead to biases in the simulated fields and processes with respect to the actual observations. For example, the model includes implicit representation of grazing, and hence loss of phytoplankton though grazing is independent of the zooplankton biomass.

While the major seasonal features of the southern $\mathrm{BoB}$ are reproduced by the model, they are often not exactly at the observed locations. For example, the SLD is slightly shifted westward and the meandering of the SMC around Sri Lanka is weaker (Fig. 12c and d), probably due to the discrepancies in the model wind forcing or the simulated remote forcings. The eastward (northward) extension of surface chlorophyll associated with the SMC is overestimated (underestimated). These inaccuracies can be ignored while examining the large-scale seasonal features but may be significant at mesoscales or smaller scales. Hence, the ecosystem model 

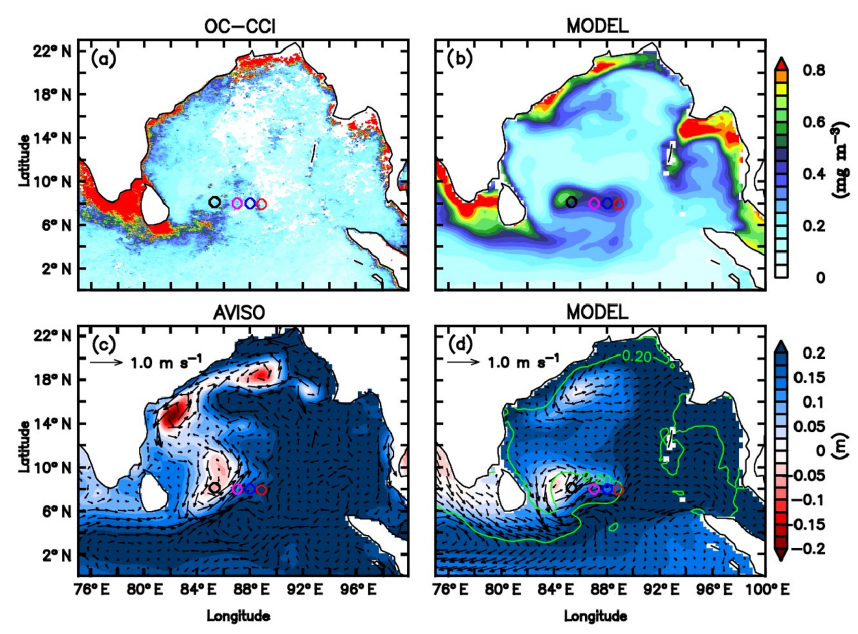

Figure 12. Comparison of the coupled physical-ecosystem model simulation with observations. Monthly mean surface chlorophyll concentrations $\left(\mathrm{mg} \mathrm{m}^{-3}\right)$ for July 2016 from (a) ESA OC-CCI merged product and (b) model. Monthly mean SLAs (m) are overlayed with surface current $\left(\mathrm{m} \mathrm{s}^{-1}\right)$ vectors from (c) AVISO and (d) model. Green contour in panel (d) represents $0.2 \mathrm{mmol} \mathrm{kg}^{-1} \mathrm{ni}$ trate isolines. The glider locations are marked as circles in the study region along $8^{\circ} \mathrm{N}$.

results are used to explain the biological response to seasonal features including the Sri Lanka Dome and the monsoon current, in comparison with the concurrent observations from gliders (SG579, SG534 and SG532) and the shipboard CTD.

The model SLD develops around $85^{\circ} \mathrm{E}, 8^{\circ} \mathrm{N}$, close to the sampling location of SG579. A longitudinal transect extending from 82 to $92^{\circ} \mathrm{E}$ along $8^{\circ} \mathrm{N}$ is selected to examine the vertical distribution of temperature, salinity, nitrate and chlorophyll on 1 July, during the peak phase of the surface chlorophyll bloom in the region of the SLD (Fig. 13). The region is characterized by an intense chlorophyll bloom $\left(\sim 0.5-0.8 \mathrm{mg} \mathrm{m}^{-3}\right)$ at the surface and a prominent DCM $\left(\sim 0.5-1.2 \mathrm{mg} \mathrm{m}^{-3}\right)$. The DCM lies below the mixed layer, centred at a depth of about $20-30 \mathrm{~m}$, and is about $10-30 \mathrm{~m}$ shallower than the nearby regions (Fig. 13a). Temperature profiles show upsloping isotherms, providing cooler $\left(27^{\circ} \mathrm{C}\right)$ waters to the surface layers (Fig. 13b). Similarly, the salinity distribution shows increased surface salinity (33.5 psu), with isohalines shoaling to the surface (Fig. 13c). Doming of the thermocline (D20) is evident between 83 and $87^{\circ} \mathrm{E}$ along the transect (Fig. 13b). The thermocline rises to a depth of $\sim 60 \mathrm{~m}$, which is about $80 \mathrm{~m}$ shallower than the nearby regions outside the dome. The surface layers were enriched with high nitrate concentrations in excess of $10 \mu \mathrm{mol} \mathrm{kg}-1$ (Fig. 13a). By the second week of July, cyclonic circulation in the region of dome weakened and shifted towards the northwest, followed by the weakening of chlorophyll.

The dynamics of the SLD favour biological productivity through the vertical transport of nutrients induced by openocean upwelling (Vinayachandran et al., 2004; Vinayachan-

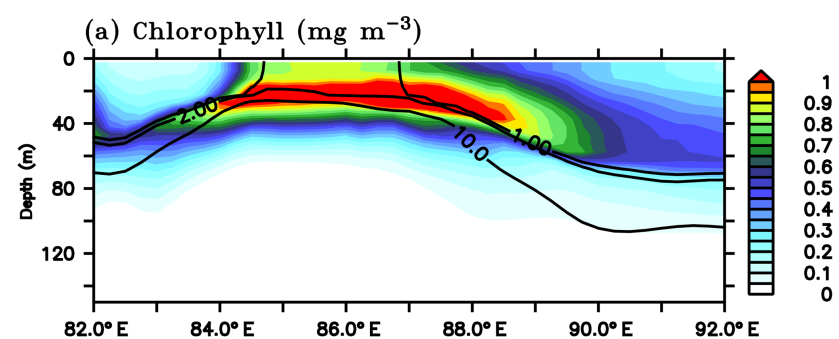

(b) Temperature $\left({ }^{0} \mathrm{C}\right)$

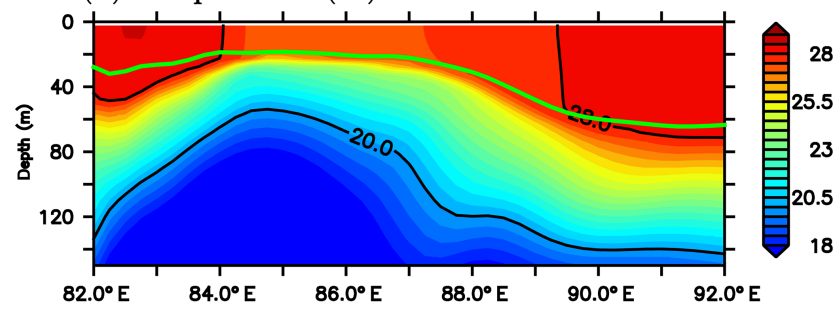

(c) Salinity (psu)

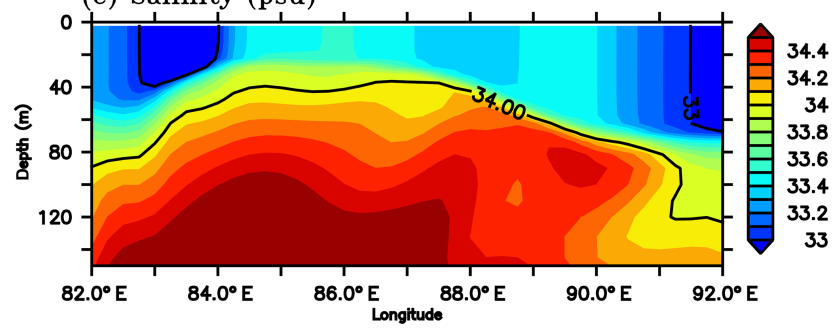

Figure 13. Depth-longitude sections of (a) chlorophyll $\left(\mathrm{mg} \mathrm{m}^{-3}\right)$, (b) temperature $\left({ }^{\circ} \mathrm{C}\right)$ and (c) salinity (psu) along $8^{\circ} \mathrm{N}$ for 1 July 2016 from the ecosystem model. Black contours in panels (a), (b) and (c) represent nitrate $\left(1,2\right.$ and $\left.10 \mu \mathrm{mol} \mathrm{kg}^{-1}\right)$, temperature $\left(20\right.$ and $28^{\circ} \mathrm{C}$ ) and salinity (33 and $34 \mathrm{psu}$ ) respectively. Green curve in panel (b) represents the model mixed layer depth.

dran, 2009). The time series of minimum SLAs in the region of the SLD shows that the modelled dome peaked on 28 June (Fig. 14), 2 days prior to the observed peak. The simulated chlorophyll bloom intensifies during the peak phase of the dome and decays with the weakening of the dome, consistent with the BoBBLE observations. The developing phase of simulated SLD (14-28 July) was characterized by the shoaling of nitracline (Fig. 14). We prefer using the $2 \mu \mathrm{mol} \mathrm{kg}{ }^{-1}$ nitrate isoline as the nitracline rather than the vertical gradient criterion, since the absolute concentration of nutrients available for phytoplankton uptake is more important for bloom generation than the gradients (Wilson and Coles, 2005). The shoaling rate of the nitracline increased to about $1.0 \mathrm{~m} \mathrm{day}^{-1}$ by mid-June and closely followed the Ekman vertical velocities. This shows that the vertical supply of nutrients to the surface layers during the developing phase of the SLD can be largely attributed to Ekman suction. During the peak phase of the SLD, both Ekman suction and nitracline shoaling rates weakened. However, the larger shoaling rates during the preceding week indicate a favourable preconditioning for the generation of chlorophyll blooms during the 


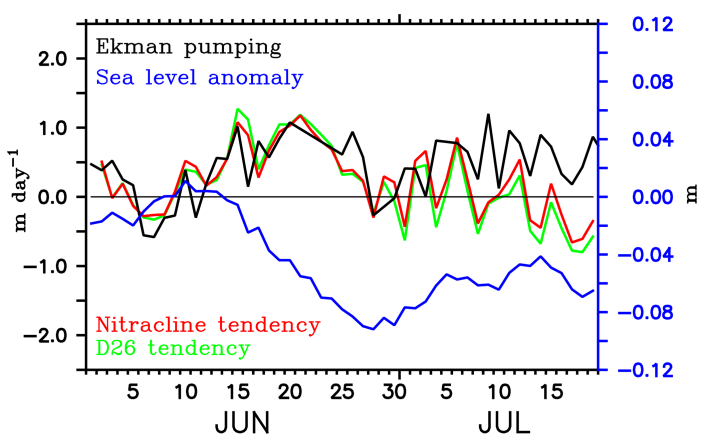

Figure 14. Ekman vertical velocity $\left(\mathrm{m} \mathrm{day}^{-1}\right.$; black) and tendencies of nitracline $\left(\mathrm{m} \mathrm{day}^{-1}\right.$; red) and D26 (m day ${ }^{-1}$; green) averaged over the region of the modelled Sri Lanka Dome. Note that the tendency terms are reversed in sign so that positive values indicate shoaling and the negative values indicate deepening. D26 is taken as the depth of the $26^{\circ} \mathrm{C}$ isotherm. Nitracline is defined as the depth of $2 \mu \mathrm{mol} \mathrm{kg}{ }^{-1}$ nitrate isoline. Minimum sea level anomaly (m; blue) in the region of the SLD is overlayed.

peak phase of the SLD. Ekman suction gradually increased during the decaying phase of the SLD. The corresponding deepening tendency of the nitracline was not consistent with the positive Ekman vertical velocities, indicating the influence of remote forcings.

Chlorophyll distribution in the region of the SMC is influenced by the horizontal advection of both nutrients and chlorophyll. Simulated surface nitrate shows enhanced concentrations along the path of the SMC, indicating the lateral advection of nutrient-rich waters from the Arabian Sea (Fig. 12d). Advection of phytoplankton from the upwelling regions off the coasts of India and Sri Lanka could further intensify the chlorophyll concentration (Vinayachandran et al., 2004; Vinayachandran, 2009). The relative role of mixed layer processes in maintaining the chlorophyll concentrations along the path of the SMC is presented in Sect. 3.3.2.

The model DCM shows large spatial variability in terms of intensity and depth. The DCM is strong in the region of the SLD and along the path of the SMC (Fig. 15a), consistent with the glider observations (Fig. 4). Subsurface chlorophyll concentrations increase to about $1.2 \mu \mathrm{mol} \mathrm{kg}-1$ within the dome, which is more than twice the concentrations outside the dome. At the same time, the depth of the DCM is minimum in the region of the SLD (Fig. 15c). The DCM shoals to $\sim 20 \mathrm{~m}$ within the dome and deepens to $\sim 70 \mathrm{~m}$ outside the dome. Productivity is closely correlated with SLAs and the depth of the nitracline and thermocline (Signorini et al., 1999, 2015; Wilson and Coles, 2005; Sarma, 2006). The strongest DCM (Fig. 15a) coincides with the shallowest nitracline (Fig. 15d). Ekman suction leads to the upsloping of nitracline, which increases the concentration of limiting nutrients in the euphotic zone. The columnintegrated chlorophyll is found to be maximum along the
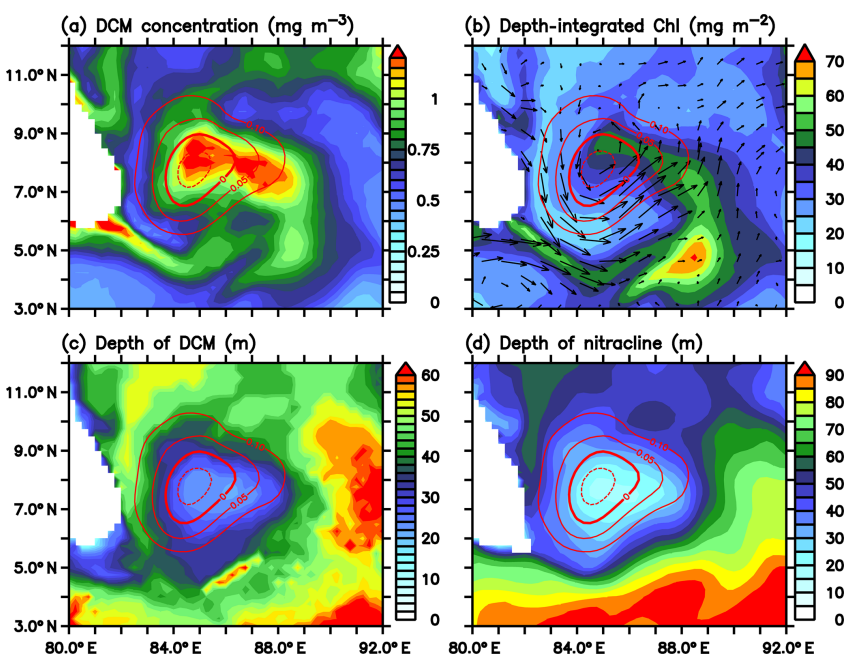

Figure 15. (a) Intensity of deep chlorophyll maxima (DCM; $\left.\mathrm{mg} \mathrm{m}^{-3}\right), \quad$ (b) depth-integrated $(100 \mathrm{~m})$ chlorophyll $\left(\mathrm{mg} \mathrm{m}^{-2}\right)$, (c) depth of DCM (m), and (d) the depth of nitracline (m) for 1 July 2016 from the ecosystem model. Nitracline is defined as the depth of $2 \mu \mathrm{mol} \mathrm{kg} \mathrm{kg}^{-1}$ nitrate isoline. Red contours in all the panels represent SLAs (m) in the region of the Sri Lanka Dome.

path of the SMC (Fig. 15b), with magnitudes ranging from 50 to $70 \mu \mathrm{mol} \mathrm{kg}^{-1}$.

\subsubsection{Mixed layer nutrient budget}

The nutrient budget from the ecosystem model is examined to identify the relative roles of mixed layer processes in controlling the summer chlorophyll distribution in the southern BoB. In the TOPAZ ecosystem model, the growth of phytoplankton is determined by a limiting nutrient in a multinutrient environment. Here, inorganic nitrate $\left(\mathrm{NO}_{3}\right)$ concentration is used to represent the nutrient budget (Fig. 16), since the dominant role of nitrate in controlling the biological productivity of the BoB is well known (Kone et al., 2009). The observed nitrate distribution has been used in previous studies to explain phytoplankton distribution in the $\mathrm{BoB}(\mathrm{Ku}-$ mar et al., 2002, 2004, 2007). The present simulation also shows that during the pre-monsoon period, productivity in the southern bay is largely limited by nitrate when mixed layer dynamics were less favourable for the vertical supply of nutrients to the surface sunlit layers. Hence $\mathrm{NO}_{3}$ was preferred over $\mathrm{PO}_{4}$ and $\mathrm{Fe}$ for explaining the nutrient distribution. In addition, the chlorophyll concentration in TOPAZ is proportional to the nitrogen in phytoplankton (Dunne et al., 2010). Total chlorophyll is calculated as

$\mathrm{Chl}=\mathrm{C}: \mathrm{N} \cdot 12 \times 10^{6} \cdot\left(\theta^{\mathrm{Sm}} \cdot N^{\mathrm{Sm}}+\theta^{\mathrm{Lg}} \cdot N^{\mathrm{Lg}}+\theta^{\mathrm{Di}} \cdot N^{\mathrm{Di}}\right)$,

where $\mathrm{C}: \mathrm{N}$ is the carbon-to-nitrogen ratio, $12 \times 10^{6}$ is the molecular mass of carbon in $\mu \mathrm{g} \mathrm{mol}^{-1}, \theta$ is the chlorophyllto-carbon ratio $(\mathrm{Chl}: \mathrm{C}$ ) and $\mathrm{N}$ is the phytoplankton nitrogen concentration in $\mathrm{mol} \mathrm{kg}^{-1}$. 

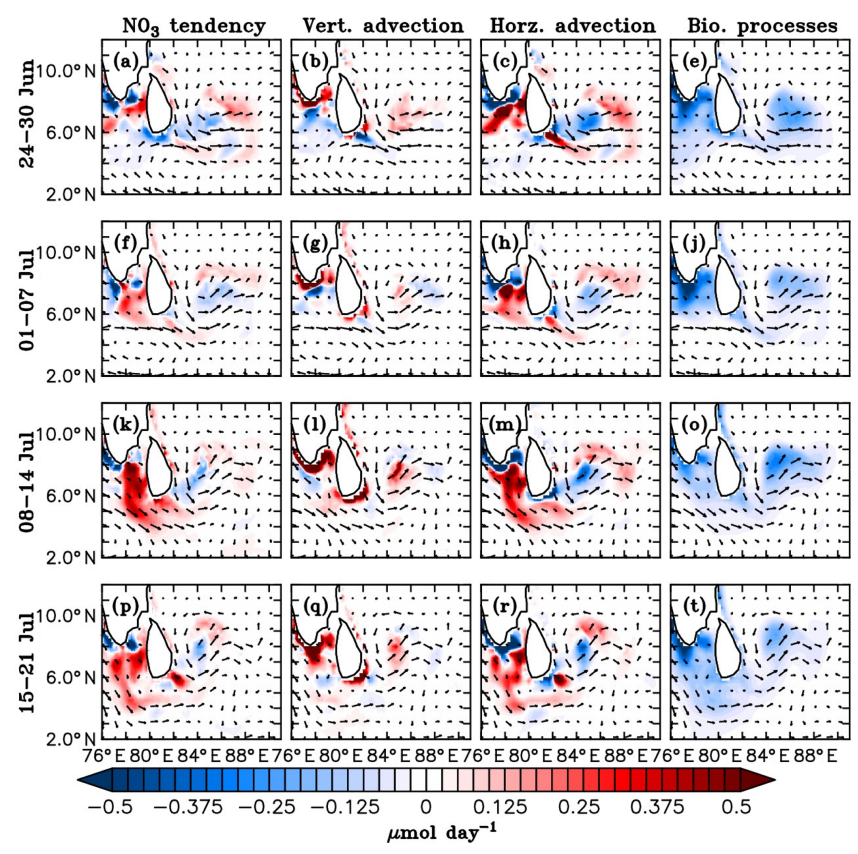

Figure 16. Model nitrate budget averaged over the mixed layer. Nitrate tendency (first column), vertical processes (second column), horizontal advection (third column) and the biological processes (fourth column) in $\mu \mathrm{mol} \mathrm{day}^{-1}$ are shown for 7-day averages starting from 24 June to 21 July 2016, marked on the left side of the corresponding panels. Vertical processes include vertical advection and mixing, and biological processes include source (nitrification) and sink (denitrification and uptake by the phytoplankton) terms for the model nitrate. Surface current $\left(\mathrm{m} \mathrm{s}^{-1}\right)$ vectors are overlayed.

Physical processes controlling the model nutrient distribution include horizontal advection and vertical processes (including vertical advection and mixing). The biological processes include a source term represented by nitrification and sink terms comprising denitrification and uptake by the phytoplankton.

The time rate of change of nitrate is given by

$$
\frac{\partial \mathrm{NO}_{3}}{\partial t}=-\nabla \cdot \boldsymbol{u} \mathrm{NO}_{3}+\nabla K \nabla \mathrm{NO}_{3}+S_{\mathrm{NO}_{3}},
$$

where $\boldsymbol{u}$ is the velocity vector from the ocean general circulation model (OGCM), $K$ is the vertical diffusivity and $\mathrm{S}_{\mathrm{NO}_{3}}$ represents the biological processes.

Weekly averages of the model nitrate budget terms averaged over the mixed layer from 24 June to 21 July, comprising the BoBBLE observational period, are shown in Fig. 16. The model MLD is defined as the depth at which the buoyancy difference with respect to the surface is equal to $0.0003 \mathrm{~m} \mathrm{~s}^{-2}$. Before the onset of the summer monsoon, the upper ocean of the southern $\mathrm{BoB}$ maintained oligotrophic conditions, where nutrient levels were weak, inhibiting the growth of phytoplankton (not shown). Mixed layer dynamics associated with the monsoonal forcings play a dominant role in controlling the nutrient distribution of the southern $\mathrm{BoB}$.
As the monsoon intensifies, the monsoon current becomes stronger and the cyclonic circulation off the eastern coast of Sri Lanka leads to the development of the Sri Lanka Dome (Fig. 12).

The last week of June, coinciding with the beginning phase of the BoBBLE observational period, was characterized by a developing phase of the SLD, with strong openocean upwelling. Nitrate concentrations in the mixed layer increased (Fig. 16a) as a result of enhanced vertical transport (Fig. 16b). At the same time, these nutrients were transported away from the region of upwelling and redistributed to the nearby regions through horizontal advection (Fig. 16c). Along the southern tip of India and Sri Lanka, coastal upwelling driven by alongshore winds leads to the intensification of nitrate levels, as evident from the vertical processes (Fig. 16b). Offshore transport of upwelled nutrients occurs at significant rates, enhancing the nitrate concentrations in regions away from the coast (Fig. 16c). Within the mixed layer, uptake by the phytoplankton is higher than nitrification so that the sink term exceeds the source term. Hence, biological processes contribute to a reduction in total nitrate, mainly in the coastal ocean and the region of SLD, where phytoplankton concentrations are high (Fig. 16d).

During the first week of July, nitrate levels in the mixed layer reduced slightly compared to the previous week; this period was characterized by the gradual weakening of the SLD and a reduction in the vertical supply of nutrients (Fig. 16f), leading to a decline in nitrate levels. Consequently, the associated horizontal transport (Fig. 16g) to the nearby regions also reduced. The nitrate uptake reduced due to the reduction in phytoplankton concentration, which explains the weaker negative tendencies due to biological processes in the region of the dome (Fig. 16h). Upwelling along the coasts of India and Sri Lanka (Fig. 16f) and the offshore advection effects (Fig. 16g) were still prominent during this period.

During the second week of July, nitrate levels in the mixed layer were generally higher compared to the previous week, especially in the region of the SMC (Fig. 16i). The SLD slightly regained its strength until 10 July and weakened immediately. The related vertical transport of nutrients intensified (Fig. 16j), and the upwelled nutrients were distributed to the nearby regions (Fig. 16k). Though the upwelling was not as strong as that in the preceding peak phase (during the last week of June), vertical supply of nitrate occurred at higher rates (Fig. 16b and j). As a result of strong upwelling in the preceding peak phase of the SLD, the nitrate isolines became shallower (not shown). This preconditioning probably favoured enhanced vertical supply of nitrate to the surface layers during the second peak phase, though the strength of upwelling was weaker.

The simulated eastward velocities associated with the summer monsoon current off the southern coast of India and Sri Lanka strengthened during the second week of July in relation to increasing wind speeds. Along the path of the SMC, a clear patch of increased nitrate levels was evident (Fig. 16i), 
which extended from the southern tip of India up to about $85^{\circ} \mathrm{E}$. This indicates horizontal advection of coastally upwelled nutrients from the southern coasts of India and Sri Lanka (Fig. 16k) into the southern BoB by the SMC. Lateral supply of nutrients by the SMC supports phytoplankton accumulation along its path. Increased uptake of nitrate by the phytoplankton further enhanced the negative contribution of biological processes (Fig. 161).

During the third week of July, nitrate levels along the path of the SMC decreased (Fig. 16m). Following a reduction in wind speed, the monsoon current off the southern coast of India weakened, and so did the horizontal transport (Fig. 160). Vertical supply of nutrients was maintained in the region of dome (Fig. 16n). Contribution by biological processes decreased as the nitrate uptake weakened following a reduction in phytoplankton concentration (Fig. 16p). In summary, the above analyses show that the distribution of nutrients and the biological productivity in the southern $\mathrm{BoB}$ is largely dependent on the mixed layer dynamics associated with the summer monsoon, and the relative roles of vertical and horizontal processes vary spatially following the circulation features.

\section{Summary and conclusions}

The BoB plays a major role in controlling the monsoon variability through its unique upper-ocean properties (Gadgil et al., 1984; Vecchi and Harrison, 2002; Shankar et al., 2007). A deeper understanding of the biophysical feedbacks in the $\mathrm{BoB}$ is of primary importance, since oceanic productivity plays a major role in modifying the air-sea heat and gas exchanges (Arrigo et al., 1999; Chisholm, 2000). Despite its climatic significance, estimates of chlorophyll distribution in the $\mathrm{BoB}$ are limited, owing to the restrictions in spatiotemporal coverage of in situ and satellite observations. In the presence of salinity stratification, which imparts strong nutrient limitation in the surface layers, high chlorophyll concentrations are mostly confined to the subsurface layers of the BoB. Hence, satellite retrieval algorithms based on ocean colour in the surface layers would lead to an underestimation of actual chlorophyll content in the water column. These limitations in data sampling imply the need for high-resolution and sustained measurements of the vertical distribution of chlorophyll in the BoB.

In this paper, we document the observed vertical distribution of chlorophyll in the southern BoB during the BoBBLE field programme conducted during the summer monsoon of 2016. High-resolution data sampling using gliders, accompanied by shipboard CTD, record high chlorophyll concentrations in the southern BoB, with persistent DCM at intermediate depths. Hydrographic features of the region suggest that the observed spatio-temporal distribution of chlorophyll is strongly linked to the competing effects of monsoonal wind and freshwater forcings, which control the light and nutrient limited growth rate of the phytoplankton. The present observations underline the previously reported (Vinayachandran et al., 2004; Vinayachandran, 2009; Jyothibabu et al., 2015) role of the SLD and the SMC as the major physical drivers determining the biological productivity of the southern BoB. The region of the SLD is characterized by enhanced chlorophyll concentrations in the presence of a shallow thermocline. A distinct band of chlorophyll is observed all along the path of the SMC, highlighting the role of lateral advection of nutrient-rich waters from the Arabian Sea in enriching the oligotrophic upper ocean of the BoB. In addition to the seasonal forcings, intermittent mixing events induced by local wind forcing trigger surface chlorophyll blooms outside the dome. A coupled physical-ecosystem model simulates the aforementioned distribution of chlorophyll satisfactorily, with prominent chlorophyll blooms in the regions of SLD and SMC. Model nutrient budget analyses demonstrate the role of monsoon dynamics in controlling the spatial and temporal distribution of biological productivity in the southern BoB. Open-ocean Ekman suction of nutrients is identified as favouring the intensification of chlorophyll in the region of the SLD. On the other hand, a reduction in chlorophyll levels during the decaying phase of the SLD can be associated with the remote forcing by the westward propagating downwelling Rossby wave signals. Advection by the SMC supplies coastally upwelled nutrients along the southern coasts of India and Sri Lanka to the southern BoB, favouring enhanced bloom concentrations. High chlorophyll concentrations observed at the subsurface indicate the contribution of DCM in the column-integrated productivity of the $\mathrm{BoB}$, where the surface waters are generally oligotrophic. Intense DCM exist in the region of the SLD and the SMC, whereas outside the dome, subsurface chlorophyll is weaker. Spatial variability of DCM intensity indicates that the dynamic uplifting of the thermocline (nutricline) is more efficient in enriching the euphotic zone with nutrients compared with wind-induced mixing. Upwelling leads to sharp and intense DCM, whereas mixing results in more diffuse and weaker DCM. The region of the subsurface intrusion of the SMC exhibits the strongest DCM among all the glider locations, suggesting the contribution of Arabian Sea water to the biological budget of the BoB.

Inhibition of surface blooms induced by the freshwater effect was often observed in the southern BoB during the study period, similar to that in the northern BoB. The intermittent occurrence of surface freshening events favours restratification of the upper ocean and formation of barrier layers. Stratification curtails the wind-induced vertical transport of nutrients and subsurface chlorophyll, leading to the decay of surface blooms. Meanwhile, freshening leads to an intensification of DCM, favoured by enhanced light penetration into deeper layers as the self-shading effect weakens in the absence of surface chlorophyll blooms. In addition, shoaling of the mixed layer induced by salinity stratification impedes the vertical redistribution of subsurface chlorophyll, thereby intensifying the DCM. 
The shape of chlorophyll profiles in different dynamical regimes indicates that the processes determining the vertical distribution of chlorophyll are intricate, which needs to be explored in detail using comprehensive datasets. The observed contrast in the vertical profiles of chlorophyll is largely dependent on the spatial extent and strength of the SMC and the SLD, which are attributed to the combined effect of local and remote forcings. Circulation and sea level anomalies reveal that the location and intensity of the SMC and SLD varied during the observational period. Using geostrophic velocities obtained from satellite data, Webber et al. (2018) showed that the SMC moved westward during the BoBBLE observational period. They related the westward shift of the SMC to the westward propagation of downwelling Rossby waves from the eastern boundary of the BoB. The strength and spatial extent of the SLD also varied accordingly. The decay period of the SLD coincided with the arrival of westward propagating high sea level anomalies associated with the Rossby wave propagation.

Chlorophyll distribution in the ocean is determined by both physical and biological processes. The intensity and depth distribution of DCM depends on a wide range of factors, including the hydrography of the upper ocean, biochemical nutrient cycling and the physiological adaptations of different phytoplankton communities. The deep chlorophyll maxima do not necessarily represent biomass maxima, since the chlorophyll-to-biomass ratio varies with different phytoplankton species as well as with nutrient and light availability at depths (Geider et al., 1997, 1998; Wang et al., 2009; $\mathrm{Li}$ et al., 2010). Other loss terms, including grazing, mortality and sinking rates, have to be taken into account for a complete description of the evolution of chlorophyll blooms. However, the lack of observational evidence on the loss terms restricts a detailed investigation on their relative importance with respect to the physical controls during different stages of the chlorophyll bloom evolution.

Bio-physical interactions in the ocean have significant impacts on climate variability through the control on upperocean dynamics (Morel, 1988; Sathyendranath et al., 1991; Murtugudde et al., 2002; Strutton and Chavez, 2004; Manizza et al., 2005). Understanding different aspects of oceanic productivity helps to determine the potential feedbacks on the climate system. Proper estimation of the vertical distribution of marine phytoplankton and the total chlorophyll content in the upper ocean will help to understand the strength of carbon cycling in the ocean. Apart from the climatic impacts, the global marine fishery production is highly dependent on the seasonal distribution of phytoplankton in the major fishing zones. Advanced data sampling using gliders, designed to operate under adverse oceanic conditions, can make significant contributions to the understanding of biogeochemical cycling of the ocean and its climatic impacts, implying the need for expanding such observations for future research. Realistic simulation of monsoonal biophysical interactions underlines the potential role of ecosystem models in explor- ing the vertical distribution of oceanic productivity, which is beyond the scope of satellites.

Data availability. Glider data were processed using the UEA glider toolbox (http://www.byqueste.com/toolbox.html, last access: 15 October 2017) and are available from AJM on reasonable request. All other datasets are publicly available from the following sources: MERRA reanalysis product provided by the Global Modeling and Assimilation Office (GMAO) and the Goddard Earth Sciences Data and Information Services Center (GES DISC) (http://disc.sci.gsfc.nasa.gov/daac-bin/DataHoldings.pl, last access: 15 November 2017), ASCAT winds from IFREMER (http: //www.ifremer.fr/cersat/en/data/data.htm, last access: 7 November 2017), SLAs from AVISO (http://www.aviso.altimetry.fr, last access: 13 June 2018), chlorophyll from ESA OC-CCI v3.1 (http: //www.esa-oceancolour-cci.org/, last access: 18 May 2018), SST and SSS from JPL PODAAC (https://podaac.jpl.nasa.gov, last access: 22 December 2017), precipitation from TRMM (http://daac. gsfc.nasa.gov/precipitation, last access: 12 November 2017), and river discharge from SAGE (http://www.sage.wisc.edu/riverdata/, last access: 12 July 2010).

Author contributions. VT and PNV performed data analysis and paper preparation. BYQ, BGMW and AJM performed the glider data correction and quality control. VT carried out the ecosystem model simulation. All the authors contributed in data interpretation.

Competing interests. The authors declare that they have no conflict of interest.

Acknowledgements. BoBBLE is a joint MoES, India-NERC, UK programme (MM/NERC-MOES-02/2014/002). The BoBBLE field experiment on board RV Sindhu Sadhana was funded by Ministry of Earth Sciences of the government of India, under the Monsoon Mission programme administered by Indian Institute of Tropical Meteorology, Pune. We are thankful to the captain, technicians and crew of RV Sindhu Sadhana for their support and co-operation. Benjamin G. M. Webber was supported by the NERC BoBBLE project (NE/L013827/1). We thank Jenson V. George for the helpful discussions. Thanks to GFDL for providing the source code of the coupled physical-ecosystem model (MOM4P1-TOPAZ). Computations were carried out at the Super Computer Education and Research Centre, Indian Institute of Science, Bangalore. Ferret has been used for data analysis and graphics.

Review statement. This paper was edited by Stefano Ciavatta and reviewed by Abhisek Chatterjee and Emmanuel Boss.

\section{References}

Anderson, G. C.: Subsurface chlorophyll maximum in the northeast Pacific Ocean, Limnol. Oceanogr., 14, 386-391, 1969. 
Arrigo, K. R., Robinson, D. H., Worthen, D. L., Dunbar, R. B., DiTullio, G. R., VanWoert, M., and Lizotte, M. P.: Phytoplankton Community Structure and the Drawdown of Nutrients and $\mathrm{CO}_{2}$ in the Southern Ocean, Science, 283, 365-367, 1999.

Banse, K.: Should we continue to use the $1 \%$ light depth for estimating the compensation depth of phytoplankton for another 70 years?, Limnol. Oceanogr., 13, 49-52, https://doi.org/10.1002/lob.200413349, 2004.

Behara, A. and Vinayachandran, P. N.: An OGCM study of the impact of Rain and River Water Forcing on the Bay of Bengal, J. Geophys. Res., 121, 2425-2446, https://doi.org/10.1002/2015JC011325, 2016.

Behrenfeld, M. J. and Boss, E. S.: Student's tutorial on bloom hypotheses in the context ofphytoplankton annual cycles, Glob. Change Biol., 24, 55-77, https://doi.org/10.1111/gcb.13858, 2017.

Blondeau-Patissier, D., Gower, J. F., Dekker, A. G., Phinn, S. R., and Brando, V. E.: A review of ocean color remote sensing methods and statistical techniques for the detection, mapping and analysis of phytoplankton blooms in coastal and open oceans, Prog. Oceanogr., 123, 123-144, 2014.

Boss, E. and Behrenfeld, M.: In situ evaluation of the initiation of the North Atlantic phytoplankton bloom, Geophys. Res. Lett., 37, L18603, https://doi.org/10.1029/2010GL044174, 2010.

Bretherton, F. P., Davis, R. E., and Fandry, C. B.: A technique for objective analysis and design of oceanographic experiments applied to MODE-73, Deep-Sea Res., 23, 559-582, https://doi.org/10.1016/0011-7471(76)90001-2, 1976.

Burns, J., Subrahmanyam, M. B., and Murty, V. S. N.: On the dynamics of the Sri Lanka Dome in the Bay of Bengal, J. Geophys. Res.-Oceans, 122, 7737-7750, https://doi.org/10.1002/2017JC012986, 2017.

Chao, Y., Li, Z., Farrara, J. D., and Huang, P.: Blended sea surface temperatures from multiple satellites and in-situ observations for coastal oceans, J. Atmos. Ocean. Tech., 26, 1435-1446, https://doi.org/10.1175/2009JTECHO592.1, 2009.

Chassignet, E. P. and Garraffo, Z. D.: Viscosity parameterization and the Gulf Stream separation, in: From Stirring to Mixing in a Stratified Ocean: Proceedings 'Aha Huliko'a Hawaiian Winter Workshop, University of Hawai'i at Mānoa, 16-19 January 2001, edited by: Muller, P. and Henderson, D., 37-41, Univ. of Hawai'i at Mānoa, Honolulu, 2001.

Chisholm, S. W.: Stirring times in the Southern Ocean, Nature, 407, 685-587, 2000.

Conkright, M. E., Levitus, S., O’Brein, T., Boyer, T. P., Antonov, J. J., and Stephens, C.: World Ocean Atlas 1998, [CD-ROM] NODC Int. Rep. 15, 16 pp., NOAA, Silver Spring, Md., 1998.

Cullen, J. J.: The deep chlorophyll maximum: Comparing vertical profiles of chlorophyll a, Can. J. Fish. Aquat. Sci, 39, 791-803, 1982.

Cullen, J. J.: Subsurface Chlorophyll Maximum Layers: Enduring Enigma or Mystery Solved?, Annu. Rev. Mar. Sci., 7, 207-239, 2015.

Dunne, J. P., Armstrong, R. A., Gnanadesikan, A., and Sarmiento, J. L.: Empirical and mechanistic models for the particle export ratio, Global Biogeochem. Cy., 19, GB4026, https://doi.org/10.1029/2004GB002390, 2005.

Sarmiento, J. L., Slater, R. D., Dunne, J., Gnanadesikan, A., and Hiscock, M. R.: Efficiency of small scale carbon mitiga- tion by patch iron fertilization, Biogeosciences, 7, 3593-3624, https://doi.org/10.5194/bg-7-3593-2010, 2010.

Eppley, R. W.: Temperature and Phytoplankton growth in the sea, Fish. B.-NOAA, 70, 1063-1085, 1972.

Eriksen, C. C., Osse, T. J., Light, R. D., Wen, T., Lehman, T. W., Sabin, P. L., Ballard, J. W., and Chiodi, A. M.: Seaglider: A Long-Range Autonomou s Underwater Vehicle for Oceanographic Research, IEEE J. Oceanic Eng., 26, 424-436, 2001.

Figa-Saldanña, J., Wilson, J. J. W., Attema, E., Gelsthorpe, R., Drinkwater, M. R., and Stoffelen, A.: The advanced scatterometer (ASCAT) on the meteorological operational (MetOp) platform: A follow on for European wind scatterometers, Can. J. Remote Sens., 28, 404-412, 2002.

Fore, A., Yueh, S. H., Tang, W., Stiles, B., and Hayashi, A.: Combined Active/Passive Retrievals of Ocean Vector Wind and Sea Surface Salinity With SMAP, IEEE T. Geosci. Remote, 54, 7396-7404, https://doi.org/10.1109/TGRS.2016.2601486, 2016.

Gadgil, S., Joseph, P. V., and Joshi, N. V.: Ocean atmosphere coupling over monsoon regions, Nature, 312, 141-143, https://doi.org/10.1038/312141a0, 1984.

Geider, R. J.: Light and temperature dependence of the carbon to chlorophyll a ratio in microalgae and cyanobacteria: implications for physiology and growth of phytoplankton, New Phytol., 106, 1-34, 1987.

Geider, R. J., Maclntyre, H. L., and Kana, T. M.: Dynamic model of phytoplankton growth and acclimation: responses of the balanced growth rate and the chlorophyll a:carbon ratio to light, nutrient-limitation and temperature, Mar. Ecol., 148, 187-200, 1997.

Geider, R. J., Maclntyre, H. L., and Kana, T. M.: A dynamic regulatory model of phytoplanktonic acclimation to light, nutrients, and temperature, Limnol. Oceanogr., 43, 679-694, 1998.

Gnanadesikan, A., Dunne, J. P., and John, J.: What ocean biogeochemical models can tell us about bottom-up control of ecosystem variability, ICES Mar. Sci., 68, 1030-1044, https://doi.org/10.1093/icesjms/fsr068, 2011.

Gnanadesikan, A., Dunne, J. P., and Msadek, R.: Connecting Atlantic temperature variability and biological cycling in two earth system models, J. Marine Syst., 133, 39-54, https://doi.org/10.1016/j.jmarsys.2013.10.003, 2014.

Gomes, H. R., Goes, J. I., and Saino, T.: Influence of physical processes and freshwater discharge on the seasonality of phytoplankton regime in the Bay of Bengal, Cont. Shelf Res., 20, 313-330, 2000.

Gregg, W. W. and Casey, N. W.: Global and regional evaluation of the SeaWiFS chlorophyll data set, Remote Sens. Environ., 93, 463-479, 2004.

Griffies, S. M., Harrison, M. J., Pacanowski, R. C., and Rosati, A.: A technical guide to MOM4, Tech. Rep. 5, Geophys. Fluid Dyn. Lab. Ocean Group, Princeton, N. J., 2004.

Huffman, G., Adler, R., Bolvin, D., Gu, G., Nelkin, E., Bowman, K., Hong, Y., Stocker, E., and Wolff, D.: The TRMM Multi-satellite Precipitation Analysis: Quasi-Global, Multi-Year, Combined-Sensor Precipitation Estimates at Fine Scale, J. Hydrometeorol., 8, 38-55, 2007.

Jensen, T. G.: Arabian Sea and Bay of Bengal exchange of salt and tracers in an ocean model, Geophys. Res. Lett., 28, 3967-3970, 2001. 
Jyothibabu, R., Vinayachandran, P. N., Madhu, N., Robin, R., Karnan, C., Jagadeesan, L., and Anjusha, A.: Phytoplankton size structure in the southern Bay of Bengal modified by the Summer Monsoon Current and associated eddies: Implications on the vertical biogenic flux, J. Marine Syst., 143, 98-119, https://doi.org/10.1016/j.jmarsys.2014.10.018, 2015.

Jyothibabu, R., Arunpandi, N., Jagadeesan, L., Karnan, C., Lallu, K. R., and Vinayachandran, P. N.: Response of phytoplankton to heavy cloud cover and turbidity in the northern Bay of Bengal, Sci. Rep.-UK, 8, 11282, https://doi.org/10.1038/s41598018-29586-1, 2018.

Kone, V., Aumont, O., Levy, M., and Resplandy, L.: Physical and Biogeochemical Controls of the Phytoplankton Seasonal Cycle in the Indian Ocean: A Modeling Study, Geoph. Monog. Series, 185, 147-166, https://doi.org/10.1029/2008GM000700, 2009.

Kumar, S. P., Muraleedharan, P. M., Prasad, T. G., Gauns, M., Ramaiah, N., de Souza, S. N., Sardesai, S., and Madhupratap, M.: Why is the Bay of Bengal less productive during summer monsoon compared to the Arabian Sea?, Geophys. Res. Lett, 29, 2235, https://doi.org/10.1029/2002GL016013, 2002.

Kumar, S. P., Nuncio, M., Narvekar, J., Kumar, A., Sardesai, S., de Souza, S. N., Gauns, M., Ramaiah, N., and Madhupratap, M.: Are eddies nature's trigger to enhance biological productivity in the Bay of Bengal?, Geophys. Res. Lett, 31, L07309, https://doi.org/10.1029/2003GL019274, 2004.

Kumar, S. P., Nuncio, M., Ramaiah, N., Sardesai, S., Narvekar, J., Fernandes, V., and Paul, J. T.: Eddy-mediated biological productivity in the Bay of Bengal during fall and spring intermonsoons, Deep-Sea Res. Pt. I, 54, 1619-1640, https://doi.org/10.1016/j.dsr.2007.06.002, 2007.

Kumar, S. P., Narvekar, J., Nuncio, M., Gauns, M., and Sardesai, S.: What drives the biological productivity of the northern Indian Ocean?, Geoph. Monog. Series, 185, 33-56, https://doi.org/10.1029/2008GM000757, 2009.

Kumar, S. P., Narvekar, J., Nuncio, M., Kumar, A., Ramaiah, N., Sardesai, S., Gauns, M., Fernandes, V., and Paul, J.: Is the biological productivity in the Bay of Bengal light limited?, Curr. Sci., 98, 1331-1339, 2010.

Kurian, J. and Vinayachandran, P. N.: Formation mechanisms of temperature inversions in the southeastern Arabian Sea, Geophys. Res. Lett., 33, L17611, https://doi.org/10.1029/2006GL027280, 2006.

Kurian, J. and Vinayachandran, P. N.: Mechanisms of formation of the Arabian Sea mini warm pool in a high resolution OGCM, J. Geophys. Res., 112, C05009, https://doi.org/10.1029/2006JC003631, 2007.

Large, W. G. and Yeager, S. G.: Diurnal to decadal global forcing for ocean and sea-ice models: the data sets and flux climatologies, Tech. rep. NCAR/TN-460+STR, Natl., Cent. for Atmos. Res., Boulder, Colo, 2004.

Large, W. G., McWilliams, J. C., and Doney, S. C.: Oceanic vertical mixing: A review and a model with a nonlocal boundary layer parameterization, Rev. Geophys., 32, 363-403, 1994.

Laws, E. A.: Evaluation of In Situ Phytoplankton Growth Rates: A Synthesis of Data from Varied Approaches, Annu. Rev. Mar. Sci., 5, 247-268, https://doi.org/10.1146/annurev-marine121211-172258, 2013.

Lee, C. M., Jinadasa, S., Anutaliya, A., Centurioni, L. R., Fernando, H. J., Hormann, V., Lankhorst, M., Rainville, L., Send,
U., and Wijesekera, H. W.: Collaborative Observations of Boundary Currents, Water Mass Variability, and Monsoon Response in the Southern Bay of Bengal, Oceanography, 29, 102-111, https://doi.org/10.5670/oceanog.2016.43, 2016.

Letelier, R. M., Karl, D. M., Abbott, M. R., and Bidigare, R. R.: Light driven seasonal patterns of chlorophyll and nitrate in the lower euphotic zone of the North Pacific Subtropical Gyre, Limnol. Oceanogr., 49, 508-519, 2004.

Li, G., Lin, Q., Ni, G., Shen, P., Fan, Y., Huang, L., and Tan, Y.: Vertical Patterns of Early Summer Chlorophyll a Concentration in the Indian Ocean with Special Reference to the Variation of Deep Chlorophyll Maximum, Journal of Marine Biology, 2012 801248, https://doi.org/10.1155/2012/801248, 2012.

Li, Q. P., Franks, P. J. S., Landry, M. R., Goericke, R., and Taylor, A. G.: Modeling phytoplankton growth rates and chlorophyll to carbon ratios in California coastal and pelagic ecosystems, J. Geophys. Res., 115, G04003, https://doi.org/10.1029/2009JG001111, 2010.

Madhu, N., Jyothibabu, R., Maheswaran, P., Gerson, V. J., Gopalakrishnan, T., and Nair, K.: Lack of seasonality in phytoplankton standing stock (chlorophyll a) and production in the western Bay of Bengal, Cont. Shelf Res., 26, 1868-1883, 2006.

Madhu, N. V., Maheswaran, P. A., Jyothibabu, R., Revichandran, C., Balasubramanian, T., Gopalakrishnan, T. C., and Nair, K. K. C.: Enhanced biological production off Chennai triggered by October 1999 super cyclone (Orissa), Curr. Sci., 82, 1472-1479, 2002.

Madhupratap, M., PrasannaKumar, S., Bhattathiri, P. M. A., DileepKumar, M., Raghukumar, S., Nair, K. K. C., and Ramaiah, N.: Mechanism of the biological response to winter cooling in the northeastern Arabian Sea, Nature, 384, 549-552, 1996.

Madhupratap, M., Gauns, M., Ramaiah, N., Kumar, S. P., Muraleedharan, P., de Sousa, S., Sardessai, S., and Muraleedharan, U.: Biogeochemistry of the Bay of Bengal: physical, chemical and primary productivity characteristics of the central and western Bay of Bengal during summer monsoon 2001, Deep-Sea Res. Pt. II, 50, 881-896, https://doi.org/10.1016/S0967-0645(02)00611$2,2003$.

Manizza, M., Quere, C. L., Watson, A. J., and Buitenhuis, E. T.: Bio-optical feedbacks among phytoplankton, upper ocean physics and sea-ice in a global model, Geophys. Res. Lett, 32, L05603, https://doi.org/10.1029/2004GL020778, 2005.

Mateus, M., Leitao, P., de Pablo, H., and Neves, R.: Is it relevant to explicitly parameterize chlorophyll synthesis in marine ecological models?, J. Marine Syst., 94, S23-S33, https://doi.org/10.1016/j.jmarsys.2011.11.007, 2012.

Matthews, A. J., Baranowski, D. B., Heywood, K. J., Flatau, P. J., and Schmidtko, S.: The Surface Diurnal Warm Layer in the Indian Ocean during CINDY/DYNAMO, J. Climate, 27, 91019122, https://doi.org/10.1175/JCLI-D-14-00222.1, 2014.

McCreary, J. P., Kohler, K. E., Hood, R. R., and Olson, D. B.: A four-component ecosystem model of biological activity in the Arabian Sea, Prog. Oceanogr., 37, 193-240, 1996.

McCreary, J. P., Murtugudde, R., Vialard, J., Vinayachandran, P. N., Wiggert, J. D., Hood, R. R., Shankar, D., and Shetye, S.: Biophysical Processes in the Indian Ocean, 9-32, American Geophysical Union, https://doi.org/10.1029/2008GM000768, 2009.

Moore, C. M., Mills, M. M., Arrigo, K. R., Berman-Frank, I., Bopp, L., Boyd, P. W., Galbraith, E. D., Geider, R. J., Guieu, C., Jac- 
card, S. L., Jickells, T. D., Roche, J. L., Lenton, T. M., Mahowald, N. M., Marañón, E., Marinov, I., Moore, J. K., Nakatsuka, T., Oschlies, A., Saito, M. A., Thingstad, T. F., Tsuda, A., and Ulloa, O.: Processes and patterns of oceanic nutrient limitation, Nat. Geosci., 6, 701-710, https://doi.org/10.1038/NGEO1765, 2013.

Morel, A.: Optical modeling of the upper ocean in relation to its biogenous matter content (case I waters), J. Geophys. Res., 93, 10749-10768, https://doi.org/10.1029/JC093iC09p10749, 1988.

Morel, A. and Antoine, D.: Heating rate within the upper ocean in relation to its bio-optical state, J. Phys. Oceanogr., 24, 16521665, 1994.

Morel, A. and Smith, R. C.: Relation between total quanta and total energy for aquatic photosynthesis, Limnol. Oceanogr., 19, 591600, 1974.

Murtugudde, R., Beauchamp, J., McClain, C. R., Lewis, M., and Busalacchi, A. J.: Effects of Penetrative Radiation on the Upper Tropical Ocean Circulation, J. Climate, 15, 470-486, 2002.

Murty, V., Sarma, M., and Tilvi, V.: Seasonal cyclogenesis and the role of near-surface stratified layer in the Bay of Bengal, paper presented at the Fifth Pacific Ocean Remote Sensing Conference, PORSEC, Goa, India, 2000.

Murty, V. S. N., Sarma, Y. V. B., Rao, D. P., and Murty, C. S.: Water characteristics, mixing and circulation in the Bay of Bengal during southwest monsoon, J. Mar. Res., 50, 207-228, 1992.

Nuncio, M. and Prasanna Kumar, S.: Evolution of cyclonic eddies and biogenic fluxes in the northern Bay of Bengal, Biogeosciences Discuss., 10, 16213-16236, https://doi.org/10.5194/bgd-10-16213-2013, 2013.

Park, J.-Y. and Kug, J.-S.: Marine biological feedback associated with Indian Ocean Dipole in a coupled ocean/biogeochemical model, Clim. Dynam., 42, 329-343, https://doi.org/10.1007/s00382-012-1640-5, 2014.

Park, J.-Y., Kug, J.-S., and Park, Y.-G.: An exploratory modeling study on bio-physical processes associated with ENSO, Prog. Oceanogr., 124, 28-41, 2014.

Pastor, M. V., Palter, J. B., Pelegri, J. L., and Dunne, J. P.: Physical drivers of interannual chlorophyll variability in the eastern subtropical North Atlantic, J. Geophys. Res., 118, 1-16, https://doi.org/10.1002/jgrc.20254, 2013.

Perry, M. J., Sackmann, B. S., Eriksen, C. C., and Lee, C. M.: Seaglider observations of blooms and subsurface chlorophyll maxima off the Washington coast, Limnol. Oceanogr., 53, 2169 2179, 2008.

Rao, K. H., Smitha, A., and Ali, M. M.: A study on cyclone induced productivity in south-western Bay of Bengal during NovemberDecember 2000 using MODIS (SST and chlorophyll-a) and altimeter sea surface height observations, Indian J. Mar. Sci., 35, 153-160, 2006.

Rienecker, M. M., Suarez, M. J., Gelaro, R., Todling, R., Bacmeister, J., Liu, E., Bosilovich, M. G. , Schubert, S. D., Takacs, L., Kim, G.-K., Bloom, S., Chen, J., Collins, D., Conaty, A., da Silva, A., Gu, W., Joiner, J., Koster, R. D., Lucchesi, R., Molod, A., Owens, T., Pawson S., Pegion, P., Redder, C. R., Reichle, R., Robertson, F. R., Ruddick, A. G., Sienkiewicz, M., and Woollen, J.: MERRA - NASA's Modern-Era Retrospective Analysis for Research and Applications, J. Climate, 24, 36243648, https://doi.org/10.1175/JCLI-D-11-00015.1, 2011.
Sarma, V. V. S. S.: The influence of Indian Ocean Dipole (IOD) on biogeochemistry of carbon in the Arabian Sea during 19971998, J. Earth Syst. Sci., 115, 433-450, 2006.

Sarmiento, J. L., Slater, R. D., Dunne, J., Gnanadesikan, A., and Hiscock, M. R.: Efficiency of small scale carbon mitigation by patch iron fertilization, Biogeosciences, 7, 3593-3624, https://doi.org/10.5194/bg-7-3593-2010, 2010.

Sathyendranath, S., Gouveia, A., Shetye, S., Ravindran, P., and Platt, T.: Biological control of surface temperature in the Arabian Sea, Nature, 349, 54-56, 1991.

Schott, F., Reppin, J., Fischer, J., and Quadfasel, D.: Currents and transports of the Monsoon Current south of Sri Lanka, J. Geophys. Res., 99, 25127-25141, https://doi.org/10.1029/94JC02216, 1994.

Sedigh Marvasti, S., Gnanadesikan, A., Bidokhti, A. A., Dunne, J. P., and Ghader, S.: Challenges in modeling spatiotemporally varying phytoplankton blooms in the Northwestern Arabian Sea and Gulf of Oman, Biogeosciences, 13, 1049-1069, https://doi.org/10.5194/bg-13-1049-2016, 2016.

Shankar, D., Vinayachandran, P., and Unnikrishnan, A.: The monsoon currents in the north Indian Ocean, Prog. Oceanogr., 52, 63-120, 2002.

Shankar, D., Shetye, S. R., and Joseph, P. V.: Link between convection and meridional gradient of sea surface temperature in the Bay of Bengal, J. Earth Syst. Sci., 116, 385-406, 2007.

Shenoi, S. S. C., Shankar, D., and Shetye, S. R.: Differences in heat budgets of the near-surface Arabian Sea and Bay of Bengal: Implications for the summer monsoon, J. Geophys. Res., 107, 3052, https://doi.org/10.1029/2000JC000679, 2002.

Shetye, S., Shenoi, S., Gouveia, A., Michael, G., Sundar, D., and Nampoothiri, G.: Wind-driven coastal upwelling along the western boundary of the Bay of Bengal during the southwest monsoon, Cont. Shelf Res., 11, 1397-1408, https://doi.org/10.1016/0278-4343(91)90042-5, 1991.

Signorini, S. R., Murtugudde, R. G., McClain, C. R., Christian, J. R., Picaut, J., and Busalacchi, A. J.: Biological and phys ical signatures in the tropical and subtropical Atlantic, J. Geophys. Res., 104, 18367-18382, 1999.

Signorini, S. R., Franz, B. A., and McClain, C. R.: Chlorophyll Variability in the Oligotrophic Gyres: Mechanisms, Seasonality and Trends, Front. Mar. Sci., 2, https://doi.org/10.3389/fmars.2015.00001, 2015.

Strutton, P. and Chavez, F.: Biological Heating in the Equatorial Pacific: Observed Variability and Potential for Real-Time Calculation, J. Climate, 17, 1097-1109, 2004.

Sweeney, C., Gnanadesikan, A., Griffies, S. M., Harrison, M. J., Rosati, A. J., and Samuels, B. L.: Impacts of shortwave penetration depth on large-scale ocean circulation and heat transport, J. Phys. Oceanogr., 35, 1103-1119, 2005.

Thomalla, S. J., Moutier, W., Ryan-Keogh, T. J., Gregor, L., and Schutt, J.: An optimized method for correcting fluorescence quenching using optical backscattering on autonomous platforms, Limnol. Oceanogr.-Methods, 16, 132-144, https://doi.org/10.1002/lom3.10234, 2018.

Thushara, V. and Vinayachandran, P. N.: Formation of summer phytoplankton bloom in the northwestern Bay of Bengal in a coupled physical-ecosystem model, J. Geophys. Res., 121, 8535-8550, 2016. 
Turk, D., McPhaden, M. J., Busalacchi, A. J., and Lewis, M. R.: Remotely sensed biological production in the equatorial Pacific, Science, 293, 471-474, 2001.

Vecchi, G. A. and Harrison, D. E.: Monsoon Breaks and Subseasonal Sea Surface Temperature Variability in the Bay of Bengal, J. Climate, 15, 1485-1493, 2002.

Vijith, V., Vinayachandran, P. N., Thushara, V., Amol, P., Shankar, D., and Anil, A. C.: Consequences of inhibition of mixed-layer deepening by the West India Coastal Current for winter phytoplankton bloom in the northeastern Arabian Sea, J. Geophys. Res.-Oceans, 121, 6583-6603, https://doi.org/10.1002/2016JC012004, 2016.

Vinayachandran, P. N.: Impact of Physical Processes on Chlorophyll Distribution in the Bay of Bengal, 71-86, American Geophysical Union, https://doi.org/10.1029/2008GM000705, 2009.

Vinayachandran, P. N. and Kurian, J.: Hydrographic observations and model simulation of the Bay of Bengal freshwater plume, Deep-Sea Res. Pt. I, 54, 471-486, 2007.

Vinayachandran, P. N. and Mathew, S.: Phytoplankton bloom in the Bay of Bengal during the northeast monsoon and its intensification by cyclones, Geophys. Res. Lett, 30, 1572, https://doi.org/10.1029/2002GL016717, 2003.

Vinayachandran, P. N. and Yamagata, T.: Monsoon Response of the Sea around Sri Lanka: Generation of Thermal Domes and Anticyclonic Vortices, J. Phys. Oceanogr., 28, 1946-1960, 1998.

Vinayachandran, P. N., Masumoto, Y., Mikawa, T., and Yamagata, T.: Intrusion of Southwest Monsoon current into Bay of Bengal, Geophys. Res. Lett, 104, 11077-11085, 1999.

Vinayachandran, P. N., Murthy, V. S. N., and Babu, V. R.: Observations of barrier layer formation in the Bay of Bengal during summer monsoon, J. Geophys. Res., 107, 8018, https://doi.org/10.1029/2001JC000831, 2002.

Vinayachandran, P. N., Chauhan, P., Mohan, M., and Nayak, S.: Biological response of the sea around Sri Lanka to summer monsoon, Geophys. Res. Lett., 31, L01302, https://doi.org/10.1029/2003GL018533, 2004.

Vinayachandran, P. N., McCreary, J. P., Hood, R. R., and Kohler, K. E.: A numerical investigation of the phytoplankton bloom in the Bay of Bengal during Northeast Monsoon, J. Geophys. Res, 110, C12001, https://doi.org/10.1029/2005JC002966, 2005.

Vinayachandran, P. N., Shankar, D., Vernekar, S., Sandeep, K. K., Amol, P., Neema, C. P., and Chatterjee, A.: A summer monsoon pump to keep the Bay of Bengal salty, Geophys. Res. Lett, 40, 1777-1782, https://doi.org/10.1002/grl.50274, 2013.

Vinayachandran, P. N., Matthews, A. J., Kumar, K. V., SanchezFranks, A., Thushara, V., George, J. V., Vijith, V., Webber, B. G. M., Queste, B. Y., Roy, R., Sarkar, A., Baranowski, D. B., Bhat, G. S., Klingaman, N. P., Parida, S. C. P. C., Heywood, K. J., Hall, R., Giddings, J., King, B., Kent, E. C., Nayak, A. A., Neema, C. P., Amol, P., Lotliker, A., Kankonkar, A., Gracias, D. G., Vernekar, S., D.Souza, A. C., Valluvan, G., Pargaonkar, S. M., and Dinesh, K.: BoBBLE (Bay of Bengal Boundary Layer Experiment): Ocean-atmosphere interaction and its impact on the South Asian monsoon, B. Am. Meteorol. Soc., 99, 1569-1587, https://doi.org/10.1175/BAMS-D-16-0230.1, 2018.
Vörösmarty, C. J., Fekete, B. M., and Tucker, B. A.: River Discharge Database, Version 1.0 (RivDIS v1.0), Volumes 0 through 6. A contribution to IHP-V Theme 1. Technical Documents in Hydrology Series, Tech. rep., UNESCO, Paris, 1996.

Wang, X. J., Behrenfeld, M., Le Borgne, R., Murtugudde, R., and Boss, E.: Regulation of phytoplankton carbon to chlorophyll ratio by light, nutrients and temperature in the Equatorial Pacific Ocean: a basin-scale model, Biogeosciences, 6, 391-404, https://doi.org/10.5194/bg-6-391-2009, 2009.

Ward, B. B., Olson, R. J., and Perry, M. J.: Microbial nitrification rates in the primary nitrite maximum off southern California, Deep-Sea Res., 29, 247-255, 1982.

Webber, B. G. M., Matthews, A. J., Heywood, K. J., Kaiser, J., and Schmidtko, S.: Seaglider observations of equatorial Indian Ocean Rossby waves associated with the MaddenJulian Oscillation, J. Geophys. Res.-Oceans, 199, 3714-3731, https://doi.org/10.1002/2013JC009657, 2014.

Webber, B. G. M., Matthews, A. J., Vinayachandran, P. N., Neema, C. P., Sanchez-Franks, A., Vijith, V., Amol, P., and Baranowski, D. B.: The dynamics of the Southwest Monsoon current in 2016 from high-resolution in situ observations and models, J. Phys. Oceanogr., 48, 2259-2282, https://doi.org/10.1175/JPOD-17-0215.1, 2018.

Wiggert, J. D., Hood, R. R., Naqvi, S. W. A., Brink, K. H., and Smith, S. L.: Introduction to Indian Ocean Biogeochemical Processes and Ecological Variability: Current Understanding and Emerging Perspectives, 1-7, American Geophysical Union, https://doi.org/10.1029/2009GM000906, 2009.

Wijesekera, H. W., Shroyer, E., Tandon, A., Ravichandran, M., Sengupta, D., Jinadasa, S. U. P., Fernando, H. J., and Coauthors ASIRI: An Ocean-Atmosphere Initiative for Bay of Bengal, B. Am. Meteorol. Soc., 97, 1859-1884, https://doi.org/10.1175/BAMS-D-14-00197.1, 2016a.

Wijesekera, H. W., Teague, W. J., Wang, D. W., Jarosz, E., and Jensen, T. G.: Low-Frequency Currents from Deep Moorings in the Southern Bay of Bengal, J. Phys. Oceanogr., 46, 3209-3238, https://doi.org/10.1175/JPO-D-16-0113.1, 2016b.

Wilson, C. and Adamec, D.: A global view of bio-physical coupling from SeaWiFS and TOPEX satellite data, 1997-2001, Geophys. Res. Lett., 29, 1257, https://doi.org/10.1029/2001GL014063, 2002.

Wilson, C. and Coles, V. J.: Global climatological relationships between satellite biological and physical observations and upper ocean properties, J. Geophys. Res., 110, C10001, https://doi.org/10.1029/2004JC002724, 2005. 